\title{
Enhancing the Emotional and Social Skills of the Youth to Promote their Wellbeing and Positive Development: A Systematic Review of Universal School-based Randomized Controlled Trials
}

\author{
Federica Sancassiani ${ }^{1,{ }^{*}}$, Elisa Pintus ${ }^{1}$, Arne Holte $^{2}$, Peter Paulus ${ }^{3}$, Maria Francesca Moro ${ }^{1}$, \\ Giulia Cossu ${ }^{1}$, Matthias C Angermeyer ${ }^{1}$, Mauro Giovanni Carta $^{1}$ and Jutta Lindert ${ }^{4}$
}

${ }^{I}$ Department of Public Health, Clinical and Molecular Medicine, University of Cagliari, Italy; ${ }^{2}$ Norwegian Institute of Public Health, Oslo, Norway; ${ }^{3}$ Institute of Psychologie \& Center for Applied Sciences of Health, Leuphana University Lueneburg, Germany; ${ }^{4}$ University of Applied Sciences Emden, Emden, Germany; Brandeis University, Waltham, USA

\begin{abstract}
Background: The acquisition of social and emotional skills is associated with positive youth development, character education, healthy lifestyle behaviours, reduction in depression and anxiety, conduct disorders, violence, bullying, conflict, and anger. School-based interventions aimed to enhance these skills go beyond a problem-focused approach to embrace a more positive view of health; they could also improve the youth's wellbeing. Aim: To describe the main features and to establish the effectiveness of universal school-based RCTs for children and the youth, aimed to promote their psychosocial wellbeing, positive development, healthy lifestyle behaviours and/or academic performance by improving their emotional and social skills. Methods: Systematic review by searching for relevant papers in PubMed/Medline with the following key words: "mental health" OR "wellbeing" OR "health promotion" OR "emotional learning" OR "social learning" OR "emotional and social learning" OR "positive youth development" OR "life skills" OR "life skills training" AND "school". Interval was set from January 2000 to April 2014. Results: 1,984 papers were identified through the search. Out of them 22 RCTs were included. While most interventions were characterized by a whole-school approach and SAFE practices, few studies only used standardized measures to assess outcomes, or had collected follow-up data after $\geq 6$ months. The results of all these trials were examined and discussed. Conclusion: Universal school-based RCTs to enhance emotional and social skills showed controversial findings, due to some methodological issues mainly. Nevertheless they show promising outcomes that are relatively far-reaching for children and youth wellbeing and therefore are important in the real world.
\end{abstract}

Keywords: Children wellbeing, emotional skills, health promotion, positive development, randomised controlled trials, school, social skills.

\section{BACKGROUND}

The WHO [1] defines mental health as "a state of wellbeing in which the individual realizes his or her own abilities, can cope with the normal stresses of life, can work productively and fruitfully, and is able to make a contribution to his or her community". Wellbeing itself is one of the aims of the WHO strategy "Health 2020", which states that mental health promotion involves building peoples' resilience against various stressors in their lives [1-6]. Resilience is defined as the universal capacity that allows a person, group or community to respond proactively to new situations and to prevent, minimize or overcome the damaging effects of adversities $[1,2,7]$.

Research shows that mental health promotion is most effective when it takes place early in a persons' life: therefore school is a favourable implementation setting for these programmes [1-4, 8-10]. The WHO [4] states that "there is ample evidence that school based programs in elementary,

*Address correspondence to this author at the Centro di Psichiatria di Consultazione e Psicosomatica, University Hospital, Cagliari, Italy; Tel: +39/070/6093495; E-mail: federicasancassiani@yahoo.it middle and high schools can positively influence mental health and reduce risk factors, emotional and behavioural problems through socio-emotional learning and ecological interventions".

Furthermore, recent evidences about school-based interventions promoting mental health and wellbeing point out the need to go beyond a problem-focused approach and embrace a more positive view of mental health $[9,11-16]$. This shift involves the acknowledgment that childrens' and youths' wellbeing and mental health are not only influenced by the absence of problems and risk-need concerns, but are also impacted by individual skills and by those positive factors in their social settings that contribute to positive growth and development $[10,12]$.

From this perspective, extensive research in school, community, and clinical settings has led several authors to offer recommendations for effective school-based interventions on emotional and social skills to promote positive youth development, mental health and wellbeing $[9,12,17$, 18]. These interventions include a whole school approach, in which multi-component interventions involve students, teachers, the school environment and the community by par- 
ticipatory ways whereby everyone, driven by common purposes, can give their own contribution from different points of view and roles, with continuous implementation for more than one year [18-20]. Furthermore, research shows four recommended practices - Sequenced, Active, Focused, Explicit - to implement good programs under the acronym SAFE [9]. The programs could be effective if they use a sequenced step-by-step training approach (Sequenced), active forms of learning (Active), devote sufficient time to skill development (Focused), and have explicit learning goals (Explicit) [21-24].

These complex features show that contemporary schools are expected to do more, but often with poorer resources than they used to have in the past [18]. A comprehensive mission for schools is not only to reach good academic achievements and knowledge, but also to promote personal and social responsibility, health, caring and citizenship and positive development for all students [18].

Positive youth development includes ecological, asset or strength-based approaches that promote healthy growth through supportive community environments and good relationships $[25,26]$. The focus is on building relationships with caring adults that support engagement in challenging activities in which the youth are active participants, rather than solely the recipients of services or support [25-28].

Catalano et al. [12] identified a set of recognizable features of positive youth development programs, some schoolbased too, which seek to achieve one or more of the following objectives: promote bonding, social, emotional, cognitive, behavioral, and moral competence; foster resilience, self-determination, spirituality, self-efficacy, clear and positive identity, belief in the future, prosocial norms (healthy standards for behavior); provide recognition of positive behavior and opportunities for prosocial involvement.

Furthermore, the WHO [8] defines life skills as "abilities for adaptive and positive behavior, that enable individuals to deal effectively with the demand and challenges of every day life". The nature and the definition of life skills are likely to differ across cultures and settings, but there is a core set of skills, as defined by the WHO [8]: decision making, problem solving, creative thinking, critical thinking, effective communication, interpersonal relationship skills, self-awareness, empathy, coping with emotions, and coping with stress.

Recent reviews have noted that certain psychosocial and developmental prevention programs such as the Life Skills Training (LST) [29-31] can be effective in preventing earlystage drug use (tobacco, alcohol, marijuana), alcohol misuse and risky sexual behaviours. LST is focused on teaching social resistance skills or a set of general life skills, either alone or in combination, and it can produce durable prevention effects [29, 32-34].

Furthermore in the 1990s', the Fetzer Insitute first introduced the term Social and Emotional Learning (SEL) to identify those interventions that can integrate the promotion of personal skills to reduce risk factors and enhance protective factors for positive youth development [12, 18, 35-38]. SEL is the process of acquiring core competencies to recognize and manage emotions, set and achieve positive goals, appreciate the perspectives of others, establish and maintain positive relationships, make responsible decisions, and handle interpersonal situations constructively [35]. SEL programs are focused on the development of a whole set of cognitive, affective, and behavioural competencies: selfawareness, self-management, social awareness, relationship skills, and responsible decision making [39]. These skills mediate better academic performance, healthy behaviours, positive social behaviours, fewer conduct problems, less emotional distress, and citizenship [18, 40, 41].

\section{AIM}

This systematic review was carried out to describe the main features and to establish the effectiveness of universal school-based RCTs for children and the young aged 0-17 years old, aimed to promote their psychosocial wellbeing, positive development, healthy lifestyle behaviors and/or academic performance by improving their emotional and social skills.

\section{METHOD}

\section{Identification of the Studies}

The search of the significant articles was carried out in PubMed/Medline with the following key words: "mental health" OR "wellbeing" OR "health promotion" OR "emotional learning" OR "social learning" OR "emotional and social learning" OR "positive youth development" OR "life skills" OR "life skills training" AND "school".

\section{Inclusion Criteria}

The studies included in this review were randomized controlled trials, in which universal school-based interventions on students' emotional and social skills to promote their wellbeing were compared to similar interventions, interventions as usual or no intervention, with samples of students aged $0-17$ years old.

Interval was set from January 2000 to April 2014.

\section{Exclusion Criteria}

Any study other than randomized controlled trials, and multiple publications on the same cohorts, studies with data analysis still pending, those conducted on indicated populations of students (i.e. at risk for some psychiatric disorder, or with low income, or belonging to ethnic minorities) and those not written in English were excluded.

The process of inclusion/exclusion of studies is summarized in Fig. (1) by Prisma Flow Diagram.

\section{Multiple Publications on the Same Cohorts}

Multiple interventions from the same report were analyzed separately if the data related to distinct outcomes or contained separate cohorts. For multiple publications evaluating the same intervention but containing different outcome data at the post-hoc or follow-up analysis for the same cohort, only the data on the last published paper were reported with reference to the others (see Tables). 


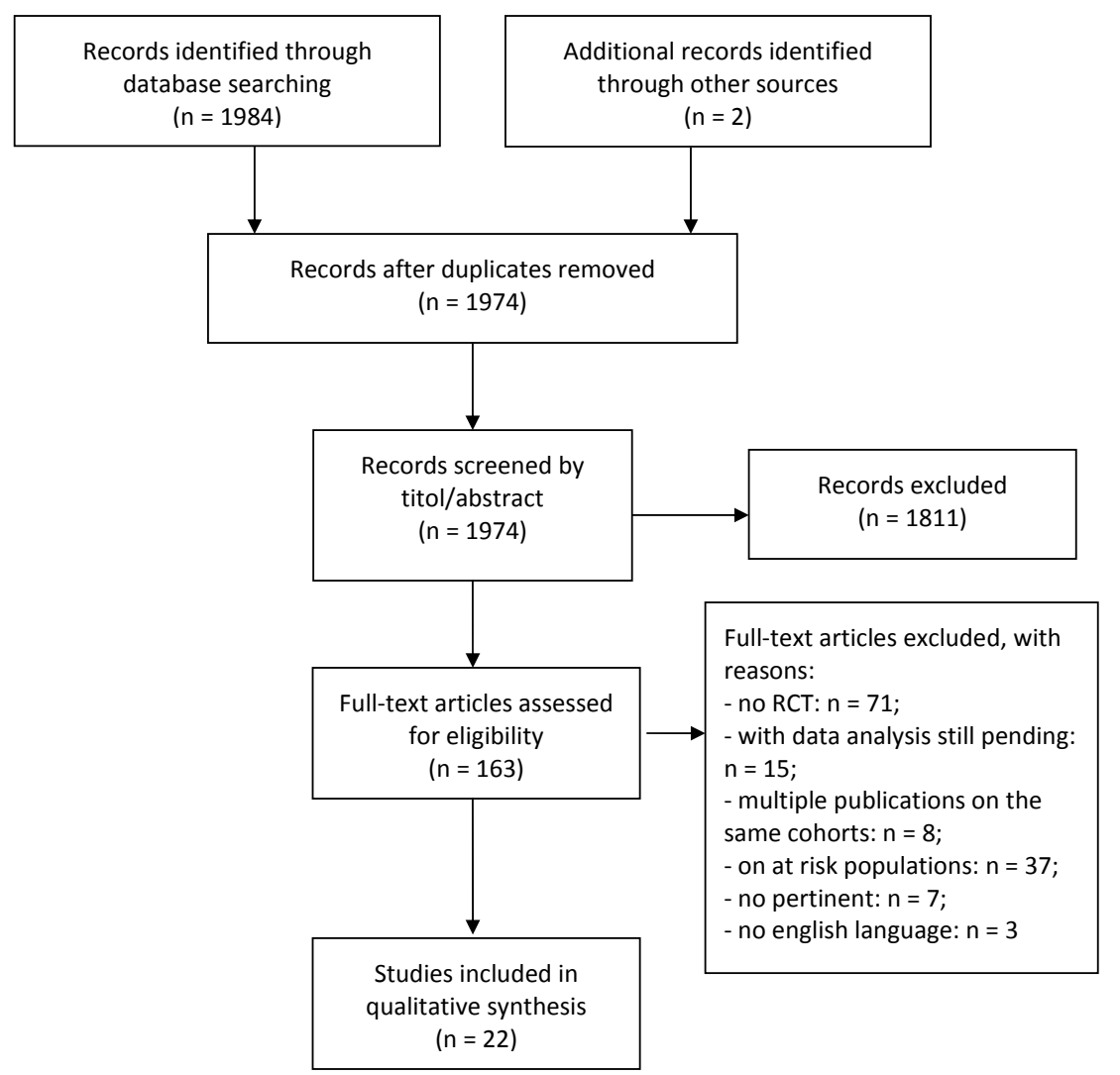

Fig. (1). Prisma flow diagram about studies' inclusion process.

\section{Studies Not Assessing Emotional or Social Skills as Me- diators}

The papers on the interventions focused on outcomes related to physical health or unhealthy behaviors only (i.e. substance abuse), without assessment of those psychological or social health variables considered as mediators by the authors, were included and summarised in dedicated tables.

\section{Content and Thematic Analysis}

Data were extracted from the included papers and organized in tables using four main criteria.

The first criterion was the kind of the implemented interventions (Life Skills Training; Life Skills Training programs focused on behavioural outcomes only; Miscellany of programs targeting psychological and social skills).

The second was the study content: Country of implementation, year of publication, students' grade, controls, sample size, whole school approach level of the intervention, duration and assessment timeline.

The third was the results: outcomes and mediators considered by the authors, measures and tools used.

The last criterion regarded the quality features of the studies (using standardised outcome measures; including $\geq 6$ months follow-up assessment after the conclusion of the intervention or waves of data across 2 academic years at least); effectiveness $(p<0.05)$; fitting characteristics of SAFE practices (Sequenced; Active; Focused; Explicit); fitting levels of whole school approach (students; teachers; parents; school environment; community). These features were coded dichotomously (yes/no).

\section{Outcomes}

We considered the main and/or secondary outcomes, as well as the mediators, as declared by the authors.

\section{RESULTS}

\section{Characteristics}

The search included 22 RCTs involving 49,169 students aged 6-18 (5-12 school grades).

Out of these, $12(54 \%)$ studies were conducted in USA [32, 42-44 (study 1 and 2), 45, 55-60], 3 (14\%) in Europe $[20,46,47]$ and $7(32 \%)$ in other countries (Australia, Canada, Mexico, South Africa, Hong Kong, Taiwan, Thailand) [48-54].

Regarding the educational level of the students participating in the studies, $1(4.5 \%)$ study involved $2^{\text {nd }}$ grade students [47] $1(4.5 \%)$ involved $3^{\text {rd }}$ grade students [55], 2 (9\%) involved $5^{\text {th }}$ grade students $[43,46], 4(18.2 \%)$ involved $6^{\text {th }}$ grade students [42, 44 (study 1 and 2), 54], 4 (18.2\%) involved $7^{\text {th }}$ grade students [32, 48, 56, 57], 2 (9\%) involved $8^{\text {th }}$ grade students $[49,52] ; 1(4.5 \%)$ involved $9^{\text {th }}$ grade students [58]; 1 (4.5\%) study involved 5-8 grades students [53], $1(4.5 \%)$ study involved 7-12 grades students [50], $1(4.5 \%)$ study involved 9-11 grades students [59], 1 (4.5\%) study involved 10-12 grades students [51], 2 (9\%) studies involved 11-12 grades students [45, 60]. 
Table 1a. "Life Skills Training” (LST) programs measuring both emotional and social skills, and healthy behavior outcomes.

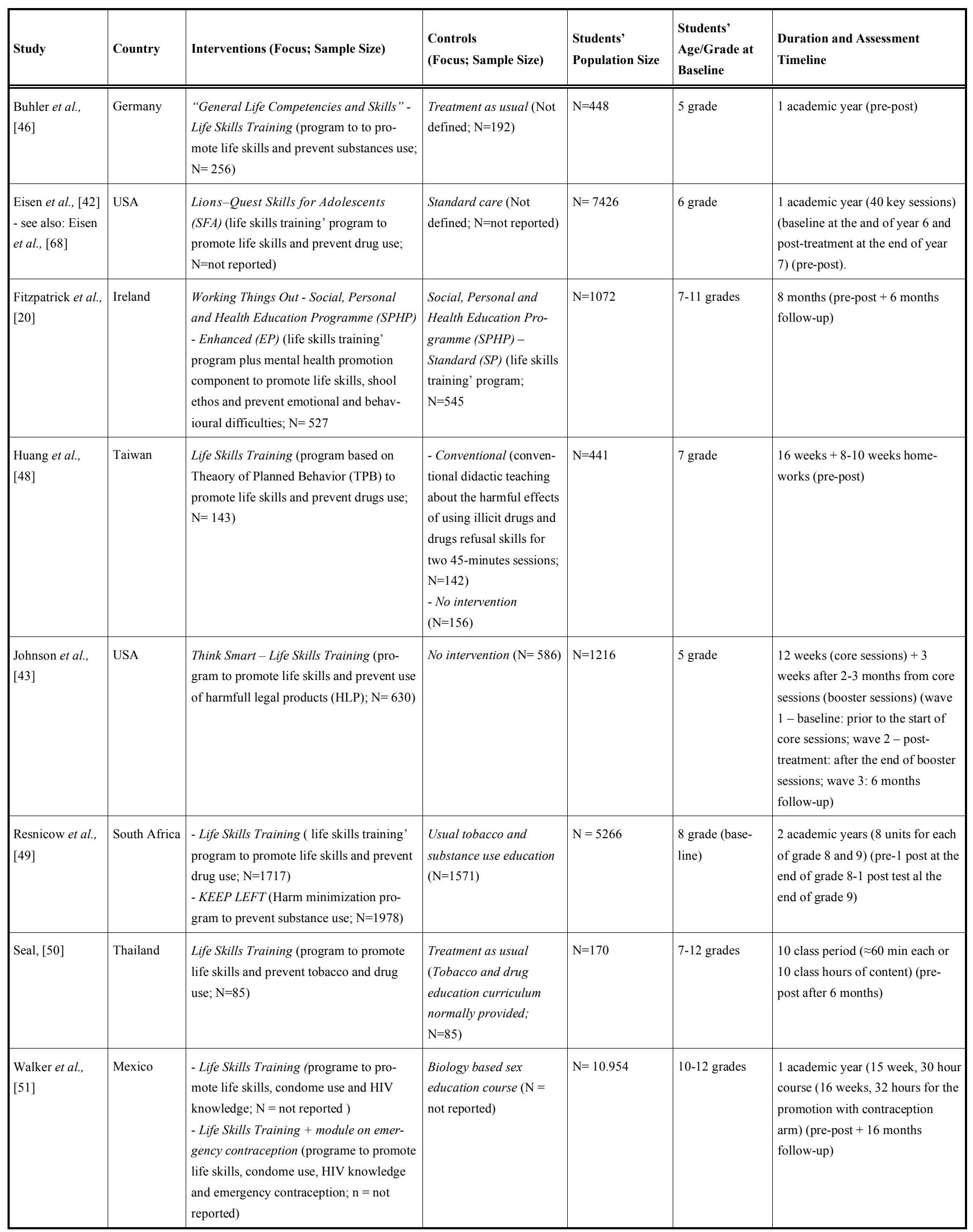


Table 1b. "Life Skills Training" (LST) programs measuring only healthy behavior outcomes.

\begin{tabular}{|c|c|c|c|c|c|c|}
\hline Study & Country & Interventions (Focus; Sample Size) & $\begin{array}{l}\text { Controls } \\
\text { (Focus; Sample Size) }\end{array}$ & $\begin{array}{l}\text { Students' } \\
\text { Population Size }\end{array}$ & $\begin{array}{l}\text { Students' } \\
\text { Age/Grade at } \\
\text { Baseline }\end{array}$ & $\begin{array}{l}\text { Duration and Assessment } \\
\text { Timeline }\end{array}$ \\
\hline $\begin{array}{l}\text { Botvin et al., } \\
\text { [32] }\end{array}$ & USA & $\begin{array}{l}\text { Life Skills Training (program to promote } \\
\text { life skills and prevent drug use; } \mathrm{N}=302 \text { ) }\end{array}$ & $\begin{array}{l}\text { Treatment as usual (Not } \\
\text { defined; } \mathrm{N}=145)\end{array}$ & $\mathrm{N}=447$ & 7 gade & $\begin{array}{l}3 \text { academic years (intervention in } \\
\text { the first academic year }+ \text { booster } \\
\text { in second and third academic } \\
\text { years) (pre-post) }\end{array}$ \\
\hline $\begin{array}{l}\text { Spoth et al., [56] } \\
\text { - see also: Spoth } \\
\text { et al., }[69 ; 70]\end{array}$ & USA & $\begin{array}{l}\text { - Iowa Strenghtening Families Program } \\
\text { (ISFP) (ISFP ia a program to enhance } \\
\text { parental skills in nurturing, limit setting, } \\
\text { and communication, as well as youth } \\
\text { prosocial and peer resistance skills to } \\
\text { reduce youth substance use and other } \\
\text { problems behaviors; } \mathrm{N}=148 \text { ) } \\
\text { - Preparing for the Drugs Free } \\
\text { Years(PDFY) (Family competency training } \\
\text { program to enhance protective parent-child } \\
\text { interactions and to reduce childrens' risk } \\
\text { for early substance use initiation; } \mathrm{N}=140 \text { ) }\end{array}$ & $\begin{array}{l}\text { Minimal contact } \text { (mailed } \\
\text { reading materials; } \mathrm{N}= \\
156)\end{array}$ & $\mathrm{N}=444$ & $\begin{array}{l}6 \text { grade (base- } \\
\text { line) }\end{array}$ & $\begin{array}{l}1 \text { academic year (ISFP duration } \\
\text { was } 7 \text { sessions (each } 2 \text { hours); } \\
\text { PDFY duration was } 5 \text { sessions } \\
\text { (each } 2 \text { hours)) (pre }+6.5 \text { years } \\
\text { past baseline (follow-up) }\end{array}$ \\
\hline $\begin{array}{l}\text { Spoth et al., } \\
\text { study } 1 \text { [44] }\end{array}$ & USA & $\begin{array}{l}\text { - Life Skills Training (LST) + Strenghten- } \\
\text { ing Families Program for parents and } \\
\text { youth 10-14 (SFP 10-14) (LST ia a pro- } \\
\text { gram to promote skills development and to } \\
\text { provide knowledge to avoid substance use; } \\
\text { SFP 10-14 ia a program to enhance paren- } \\
\text { tal skills in nurturing, limit setting, and } \\
\text { communication, as well as youth prosocial } \\
\text { and peer resistance skills to reduce youth } \\
\text { substance use and other problems behav- } \\
\text { iors; N = 189); } \\
\text { - Life Skills Training (LST) only; N = } \\
\text { 208) }\end{array}$ & $\begin{array}{l}\text { Minimal contact } \text { (mailed } \\
\text { reading materials; } N= \\
196)\end{array}$ & $N=593$ & $\begin{array}{l}6 \text { grade (base- } \\
\text { line) }\end{array}$ & $\begin{array}{l}2 \text { academic years ((LST duration } \\
\text { was } 15 \text { session in } 7 \text { grade }+5 \\
\text { booster sessions taugh } 1 \text { year later; } \\
\text { SFP } 10-14 \text { duration was } 7 \text { con- } \\
\text { secutive weeks when youth were } \\
\text { in } 7 \text { grade }+4 \text { booster session } \\
\text { taugh } 1 \text { year later) (pre }+4.5 \text { years } \\
\text { past baseline ( } 1 \text { follow-up) }+5.5 \\
\text { years past baseline ( } 2 \text { follow-up) }\end{array}$ \\
\hline $\begin{array}{l}\text { Spoth et al., } \\
\text { study } 2[44]\end{array}$ & USA & $\begin{array}{l}\text { - Life Skills Training (LST) + Strenghten- } \\
\text { ing Families Program for parents and } \\
\text { youth 10-14 (SFP 10-14) (LST ia a pro- } \\
\text { gram to promote skills development and to } \\
\text { provide knowledge to avoid substance use; } \\
\text { SFP 10-14 ia a program to enhance paren- } \\
\text { tal skills in nurturing, limit setting, and } \\
\text { communication, as well as youth prosocial } \\
\text { and peer resistance skills to reduce youth } \\
\text { substance use and other problems behav- } \\
\text { iors; } \mathrm{N}=543 \text { ); } \\
\text { - Life Skills Training (LST) only; } \mathrm{N}= \\
622 \text { ) }\end{array}$ & $\begin{array}{l}\text { Minimal contact } \text { (mailed } \\
\text { reading materials; } \mathrm{N}= \\
489 \text { ) }\end{array}$ & $\mathrm{N}=1677$ & $\begin{array}{l}7 \text { grade (base- } \\
\text { line) }\end{array}$ & $\begin{array}{l}2 \text { academic years (LST duration } \\
\text { was } 15 \text { session in } 7 \text { grade }+5 \\
\text { booster sessions in } 8 \text { grade; SFP } \\
10-14 \text { duration was } 7 \text { consecutive } \\
\text { weeks when youth were in } 7 \text { grade } \\
+4 \text { booster session while youth } \\
\text { were in } 8 \text { rade) (pre }+5 \text { repeted } \\
\text { measures during } 8-12 \text { grade (post } \\
\text { and follow-up) }\end{array}$ \\
\hline $\begin{array}{l}\text { Young et al., } \\
\text { [58] }\end{array}$ & USA & $\begin{array}{l}\text { - Life Skills Training + standard physical } \\
\text { education (program to enhance decision } \\
\text { making about the personal benefits of a } \\
\text { physically active lifestyle, develop } \\
\text { problem- } \\
\text { solving skills, and obtain support from } \\
\text { others + school- standard physical } \\
\text { education; } \mathrm{N}=116 \text { ) }\end{array}$ & $\begin{array}{l}\text { - School physical educa- } \\
\text { tion (Standard physical } \\
\text { education curriculum in } \\
\text { which students were } \\
\text { taught skills in individual } \\
\text { and team sports; } \mathrm{N} \\
=.105 \text { ) }\end{array}$ & $\mathrm{N}=221$ & 9 grader & 1 academic year (pre-post) \\
\hline
\end{tabular}


Table 1c. Different programs (than LST) on emotional and social skills, psychological wellbeing indicators, healthy behaviors, academic performance outcomes.

\begin{tabular}{|c|c|c|c|c|c|c|}
\hline Study & Country & Interventions (Focus; Sample Size) & $\begin{array}{l}\text { Controls } \\
\text { (Focus; Sample Size) }\end{array}$ & $\begin{array}{l}\text { Students' } \\
\text { Population Size }\end{array}$ & $\begin{array}{l}\text { Students' } \\
\text { Age/Grade at } \\
\text { Baseline }\end{array}$ & $\begin{array}{l}\text { Duration and Assessment } \\
\text { Timeline }\end{array}$ \\
\hline Bond et al., [52] & Australia & $\begin{array}{l}\text { Gatehouse Project (program on emotional } \\
\text { wellbeing promotion to prevent substances } \\
\text { use; baseline: } \mathrm{N}=1335 \text { ) }\end{array}$ & $\begin{array}{l}\text { No intervention } \\
(\mathrm{N}=1343)\end{array}$ & $\mathrm{N}=2678$ & 8 grade & $\begin{array}{l}3 \text { academic years ( } 4 \text { waves of } \\
\text { students: baseline at the beginning } \\
\text { of year } 8 \text {; other assessments: at the } \\
\text { and of year } 8,9,10 \text { (pre-post) }\end{array}$ \\
\hline He et al., [53] & Canada & $\begin{array}{l}\text { Free Fruit and Vegetable Snacks (FFVS) } \\
\text { plus Enhanced Nutrition Education (ENE) } \\
\text { (program offering either one fruit or one } \\
\text { vegetable serving three time per week plus } \\
\text { "Paint Your Plate! Create a Master Piece: } \\
\text { Vegetables and Fruit Action Guide for } \\
\text { Schools", a curriculum-based resources for } \\
\text { teachers to enhance students' awareness, } \\
\text { knowledge, self-efficacy, preference, } \\
\text { intention and willingness to increase fruit } \\
\text { and vegetable consumption; } \mathrm{N}=3104 \text { ) }\end{array}$ & $\begin{array}{l}\text { - Free Fruit and Vegeta- } \\
\text { ble Snacks (FFVS) } \\
\text { (program offering either } \\
\text { one fruit or one vegetable } \\
\text { serving three time per } \\
\text { week; } \mathrm{N}=1625) \\
\text { - No intervention } \\
(\mathrm{N}=1659)\end{array}$ & $\mathrm{N}=6388$ & $5-8$ grades & 21 weeks (pre-post) \\
\hline Holen et al., [47] & Norway & $\begin{array}{l}\text { Zippis' Friends (program to strenght } \\
\text { childrens' coping skills; } \mathrm{N}=686 \text { ) }\end{array}$ & $\begin{array}{l}\text { No intervention }(\mathrm{N}= \\
638)\end{array}$ & $\mathrm{N}=1324$ & 2 grade & 24 weeks (pre-post) \\
\hline Jones et al., [55] & USA & $\begin{array}{l}\text { 4Rs Social-Emotional Learning Program } \\
\text { (Reading, wRiting, Respect and Resolu- } \\
\text { tion) (program to prevent social-emotional, } \\
\text { behavioral and academic problems; } \\
\mathrm{N}=630 \text { ) }\end{array}$ & No intervention $(\mathrm{N}=554)$ & $\mathrm{N}=1184$ & 3 grade & $\begin{array}{l}2 \text { academic years (wave } 1 \text { - } \\
\text { baseline, fall third grade; wave } 2 \text { - } \\
\text { spring third grade; wave } 3 \text { - fall } \\
\text { fourth grade; wave } 4 \text { - spring } \\
\text { fourth grade) }\end{array}$ \\
\hline $\begin{array}{l}\text { Khalsha et al., } \\
\text { [57] }\end{array}$ & USA & $\begin{array}{l}\text { Yoga Ed Program (program to increase } \\
\text { psychosocial wellbeing and mental health; } \\
\mathrm{N}=74 \text { ) }\end{array}$ & $\begin{array}{l}\text { Regular physical educa- } \\
\text { tion (Not defined; } \mathrm{N}=47 \text { ) }\end{array}$ & $\mathrm{N}=121$ & 7 grade & 11 weeks (pre-post) \\
\hline $\begin{array}{l}\text { Melnik et al., } \\
\text { [59] }\end{array}$ & USA & $\begin{array}{l}\text { COPE (Creating Oppurtunities for Per- } \\
\text { sonal Empowerment) Healthy Lifestyles } \\
\text { TEEN (Thinking, Emotions, Exercise, } \\
\text { Nutrition) Program (cognitive-behavioral } \\
\text { skills-building intervention with } 20 \\
\text { minutes of physical activity integrated into } \\
\text { a health course to promote healthy life- } \\
\text { styles behaviors, good MBI, good psycho- } \\
\text { social outcomes, social skills, and aca- } \\
\text { demic performance; } \mathrm{N}=358 \text { ) }\end{array}$ & $\begin{array}{l}\text { Attention program } \\
\text { (Healthy Teen) (manual- } \\
\text { ized attenction program } \\
\text { focused on safety and } \\
\text { common health } \\
\text { topic/issue for teens. } \\
\text { Control students received } \\
\text { also a manual with } \\
\text { homeworks and reviewed } \\
\text { with their parents a } \\
\text { newsletter sent to their } \\
\text { homes; } \mathrm{N}=421 \text { ) }\end{array}$ & $\mathrm{N}=779$ & 9-11 grades & $\begin{array}{l}15 \text { weeks (pre-post }+6 \text { months } \\
\text { follow up) }\end{array}$ \\
\hline $\begin{array}{l}\text { Noogle et al., } \\
{[60]}\end{array}$ & USA & $\begin{array}{l}\text { Kripalu Yoga (program to increase psy- } \\
\text { chosocial wellbeing and self-regulatory } \\
\text { skills; } \mathrm{N}=36 \text { ) }\end{array}$ & $\begin{array}{l}\text { Regular physical educa- } \\
\text { tion (Not defined; } \mathrm{N}=15 \text { ) }\end{array}$ & $\mathrm{N}=51$ & $11-12$ grades & 10 weeks (pre-post) \\
\hline $\begin{array}{l}\text { Shek et al. }[54] \\
\text { - see also: } \\
\text { Shek et al.,; } \\
{[71 ; 72 ;} \\
73 ; 74 ; \\
75 ; 76]\end{array}$ & Hong Kong & $\begin{array}{l}\text { PATHS (Positive Adolescent Training } \\
\text { through Holistic Social Programmes) } \\
\text { (programme to promote positive develop- } \\
\text { ment and reduce risks/problem behaviors; } \\
\mathrm{N}=2662 \text { ) }\end{array}$ & $\begin{array}{l}\text { No intervention } \\
(\mathrm{N}=3272)\end{array}$ & $\mathrm{N}=5934$ & $\begin{array}{l}6 \text { grade (base- } \\
\text { line) }\end{array}$ & $\begin{array}{l}3 \text { academic years ( } 400 \text { hours in } \\
\text { each school year for each grade) } \\
\text { ( } 8 \text { year waves: pre- } 5 \text { measures }+2 \\
\text { post interventions) }\end{array}$ \\
\hline
\end{tabular}


(Table 1c.) contd....

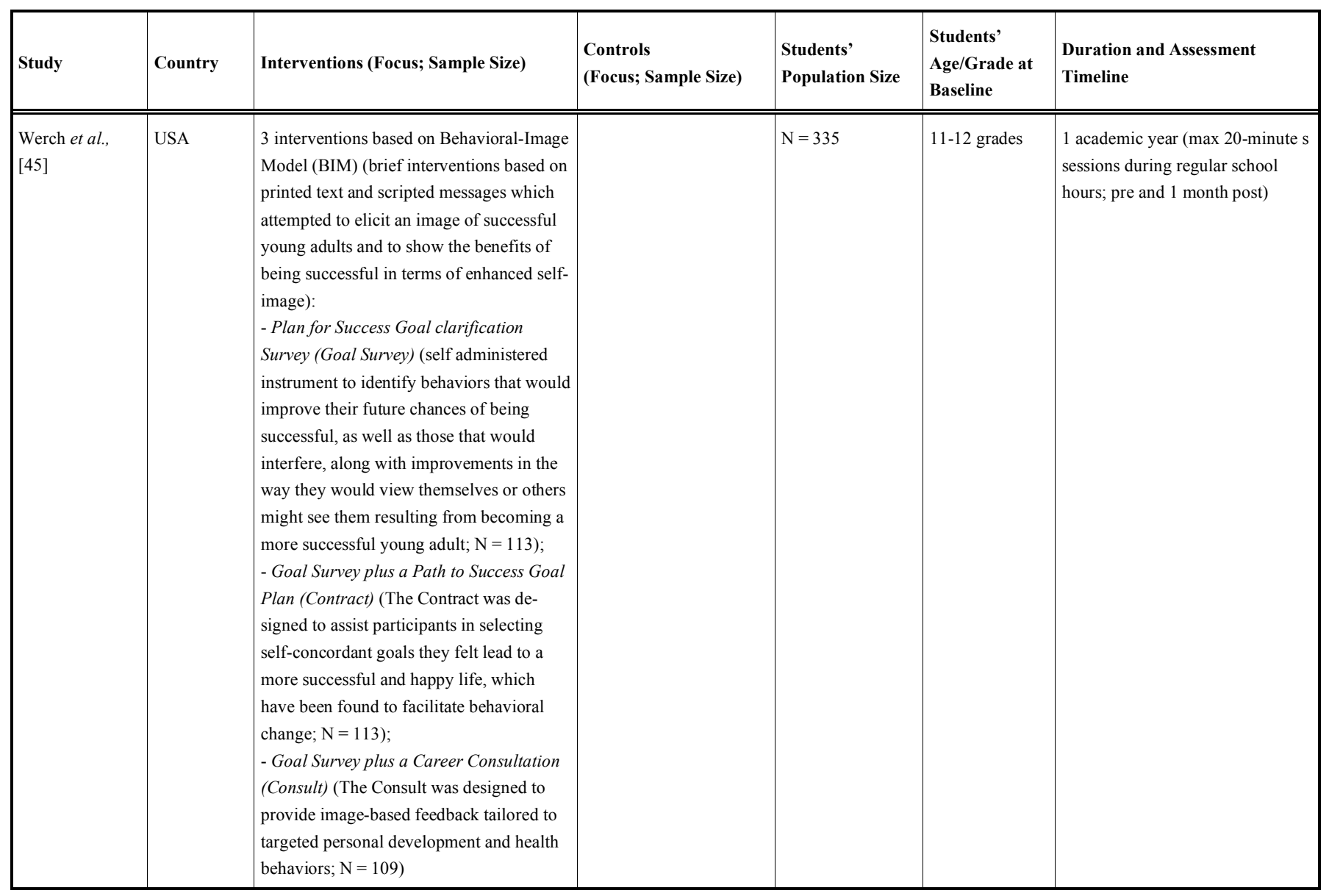

19 studies were published in 2006-2014 (86\%) [20, 43, 44 (study 1 and 2), 45-51, 53-60]; 3 (14\%) studies were published in 2000-2005 [32, 42, 52].

\section{Kind of the Interventions Implemented}

Life Skills Training (LST) was the kind of intervention tested in $13(59 \%)$ trials [20, 32, 42-44, 46, 48-51, 56, 58]. Among them, 5 (38.5\%) were conducted by testing effectiveness of LST on healthy behaviours without assessing social and psychological skills as secondary outcomes or mediators [32, 44 (study 1 and 2), 56, 58].

Regarding the studies measuring the efficacy of Life Skills Training (LST) on both social and emotional skills, and healthy behaviours, $6(75 \%)$ of them took into account both kinds of outcomes [42, 43, 46, 49-51]; 2 (25\%) trials considered social and emotional skills only [20,48].

Finally, 9 (41\%) trials had miscellanea of different programs on students' wellbeing outcomes (emotional and social skills, healthy lifestyle behaviors, academic performance, psychological wellbeing) $[45,47,52-55,57,59,60]$.

\section{Quality Features of the Studies}

Regarding the use of standardized outcome measures, 10 $(45 \%)$ trials were conducted with standardized tools [32, 42, $45,47,53,54,55,57,59,60] .3$ (14\%) studies used both standardized and not-standardized measures $[20,52,58]$.
Finally, $9(41 \%)$ studies were not conducted by standardized tools [43, 44 (study 1 and 2), 46, 48-51, 56].

Regarding the assessment timeline, 9 (41\%) studies included a $\geq 6$ month follow-up after the end of the intervention [20, 43, 44 (study 1 and 2), 50, 51, 54, 56, 59]. Among them, $4(18 \%$ of 22$)$ included also at least two academic years of repeated measures (data waves) [44 (study 1 and 2), $54,56]$. Only $2(9 \%)$ studies reported at least two academic years of repeated measures (data waves) design without $\mathrm{a} \geq 6$ month follow-up after the end of the intervention $[52,55]$. Finally, $11(50 \%)$ studies reported neither a $\geq 6$ month follow-up after the end of the intervention, nor a minimum of two academic years of repeated measures (data waves) [32, $42,45-49,53,57,58,60]$.

Regarding SAFE (Sequenced, Active, Focused, Explicit) practices, in all of $22(100 \%)$ trials at least three of these practices were used.

The whole school approach levels were the same in 12 (54.5\%) studies, which means that the interventions involved students, their teachers and the school environment but not their parents and community [32, 42-44 (study 2), 46-49, 51, $52,55,56]$. In $2(9 \%)$ studies, interventions involved students, their teachers, the school environment and the community but not their parents [20, 53]. 2 (9\%) studies focused on interventions that involved only students, without the engagement of their parents and teachers, the school environment and the community $[50,57] .4(18.2 \%)$ trials 
Table 2a. Outcomes and tools: "Life Skills Training" (LST) programs measuring emotional and social skills and/or healthy behavior outcomes.

\begin{tabular}{|c|c|c|c|}
\hline Study & Outcomes & Mediators or Covariates & Measures/Tools \\
\hline Buhler et al., [46] & $\begin{array}{l}\text { Healthy behaviors: } \\
\text { - tobacco and alcohol' use } \\
\text { - affinity toward tobacco and alcohol } \\
\text { Emotional and social skills: } \\
\text { - Knowledge about life skills and life skills } \\
\text { behaviors (self-awareness and empathy, } \\
\text { creative and critical thinking, communica- } \\
\text { tion and interpersonal relation- } \\
\text { ships, decision making and problem solv- } \\
\text { ing and coping with stress and emotions + } \\
\text { refusal assertiveness). }\end{array}$ & & $\begin{array}{l}\text { not standardized scales: } \\
\text { - respondents were asked whether they had ever used } \\
\text { tobacco or alcohol (response format: 'yes, several times', } \\
\text { 'yes, I tried' and 'no') and whether they had used it in the } \\
\text { past } 30 \text { days. Current users reported frequency of use } \\
\text { during the past } 30 \text { days and amount of use per occasion. } \\
\text { The amount of alcohol use per occasion was reported in a } \\
\text { free format. } \\
\text { Subsequently, data were dichotomized into 'abuse' and 'no } \\
\text { use/experimental use'. } \\
\text { - "Tobacco and Alcohol Distance" are two scales developed } \\
\text { to predict later substance use behavior (not standardized). } \\
\text { - "Life Skills Behaviors": } 33 \text { items scale }+3 \text { items taken } \\
\text { from Botvins' questionnaire indicating refusal assertiveness } \\
\text { (developed by authors) }\end{array}$ \\
\hline $\begin{array}{l}\text { Eisen } \text { et al., [42] } \\
\text { - see also: } \\
\text { Eisen et al., [68] }\end{array}$ & $\begin{array}{l}\text { Healthy behaviors: } \\
\text { - tobacco, alcohol and illega/illicitl drugs use } \\
\text { Emotional and social skills: } \\
\text { - behavioral intention to use tobacco, alcohol, } \\
\text { marijuana and cocaine in the next } 3 \text { months } \\
\text { - social influences } \\
\text { - interpersonal perceptions } \\
\text { - perception of harmful effects of drugs } \\
\text { - communication skills } \\
\text { - self efficacy } \\
\text { - sensation-seeking }\end{array}$ & $\begin{array}{l}\text { - sociodemographics (gender, age, family } \\
\text { structure/household composition, } \\
\text { race/ethnicity) }\end{array}$ & $\begin{array}{l}\text { - } 3 \text { cigarette smoking questions estabilished by the National } \\
\text { Cancer Institute as standard items } \\
\text { standard questions adapted from Monitoring the Future (MTF) } \\
\text { study for alcohol, marijuana, cocaine and other illegal/illicit } \\
\text { drugs use: } \\
\text { - item from (MTF) for behavioral intention to use } \\
\text { - standard questions on normative beliefs about the prevalence } \\
\text { of substance use by a best friend, friend in general and same } \\
\text { grade-peer } \\
\text { - } 3 \text { items scale on whether using alcohol, cigarettes and mari- } \\
\text { juana make it easier to "fit in". } \\
\text { - } 3 \text { items scales focusing on wheather alcohol/being drinking, } \\
\text { smoking/marijuana, cocaine help or harm ones' health, ability } \\
\text { to relax, and popularity } \\
\text { - } 3 \text { items scales to assess self efficacy around refusing the use } \\
\text { of alcohol, cicarettes/marijuana, cocain in various situations } \\
\text { - } 2 \text { items scale for perceived parent monitoring of students' } \\
\text { behaviors } \\
\text { - demographic variables scale }\end{array}$ \\
\hline $\begin{array}{l}\text { Fitzpatrick et al., } \\
{[20]}\end{array}$ & $\begin{array}{l}\text { Emotional and social skills: } \\
\text { - prosocial behaviour } \\
\text { - emotional and behavioural difficulties } \\
\text { - active coping, support seeking and less use } \\
\text { of avoidance } \\
\text { - help-seeking } \\
\text { - students' views of } \\
\text { school social environment }\end{array}$ & $\begin{array}{l}\text { - Sociodemographics (gender) } \\
\text { - Cut off scores of mental problems (Clini- } \\
\text { cal/Normal) }\end{array}$ & $\begin{array}{l}\text { - The strengths and difficulties questionnaire (SDQ) } \\
\text { - The childrens' coping strategies checklist (CCSC) } \\
\text { - help-seeking questionnaire (not standardized) } \\
\text { - 'What is your school like?' questionnaire (not standardized) }\end{array}$ \\
\hline Huang et al., [48] & $\begin{array}{l}\text { Emotional and social skills: } \\
\text { - Theory of Planned Behaviors' constructs: } \\
\text { (intention not to use illicit drugs; attitude, } \\
\text { subjective norm, perceived behavioral con- } \\
\text { trol); } \\
\text { - life skills }\end{array}$ & & $\begin{array}{l}\text { - questionnaire for Theory of Planned Behaviors' constructs } \\
\text { (not standardized) } \\
\text { - } 16 \text { items questionnaire for life skills (not standardized) }\end{array}$ \\
\hline $\begin{array}{l}\text { Johnson et al., } \\
\text { [43] }\end{array}$ & $\begin{array}{l}\text { Healthy behaviors: } \\
\text { - Harmfull Legal Products (HLP) use (inha- } \\
\text { lants, prescription medicines, over-the- } \\
\text { counter medications, common household } \\
\text { products) } \\
\text { - substance use (tobacco, alcohol, marijuana } \\
\text { or hashish } \\
\text { Emotional and social skills: } \\
\text { - Risk factors (Peer Use of HLPs; Peer } \\
\text { Normative Beliefs about HLPs); } \\
\text { - Protective factors (Knowledge of Drugs and }\end{array}$ & $\begin{array}{l}\text { - Community/School-Level Characteristics } \\
\text { (community population (2006), percentage of } \\
\text { White population in the community, poverty } \\
\text { rate, average experience level of teachers, } \\
\text { number of vandalism incidents, number of } \\
\text { enrolled students, number of suspensions and } \\
\text { expulsions (across nine possible types), } \\
\text { number of school incidents (across nine } \\
\text { possible types), rate of in-migration, rate of } \\
\text { out-migration, proportion of students eligible } \\
\text { for free or reduced-price lunch, and school }\end{array}$ & $\begin{array}{l}\text { - questionnaire for tobacco, alcohol, marijuana, inhalants, } \\
\text { prescription medicines, and } \\
\text { over-the-counter medications use (taken from Arthur et al., } \\
\text { 1998, not standatdized); } \\
\text { - questionnaire for common household products' use (not } \\
\text { standardized); } \\
\text { - } 4 \text { items for Peer Use of HLPs (modified from Hansen and } \\
\text { McNeal, 1997, not standardized); } \\
\text { - } 4 \text { items for Peer Normative } \\
\text { Beliefs about HLPs (modified from Hansen and McNeal, 1997, } \\
\text { not standardized); }\end{array}$ \\
\hline
\end{tabular}


(Table 2a.) contd....

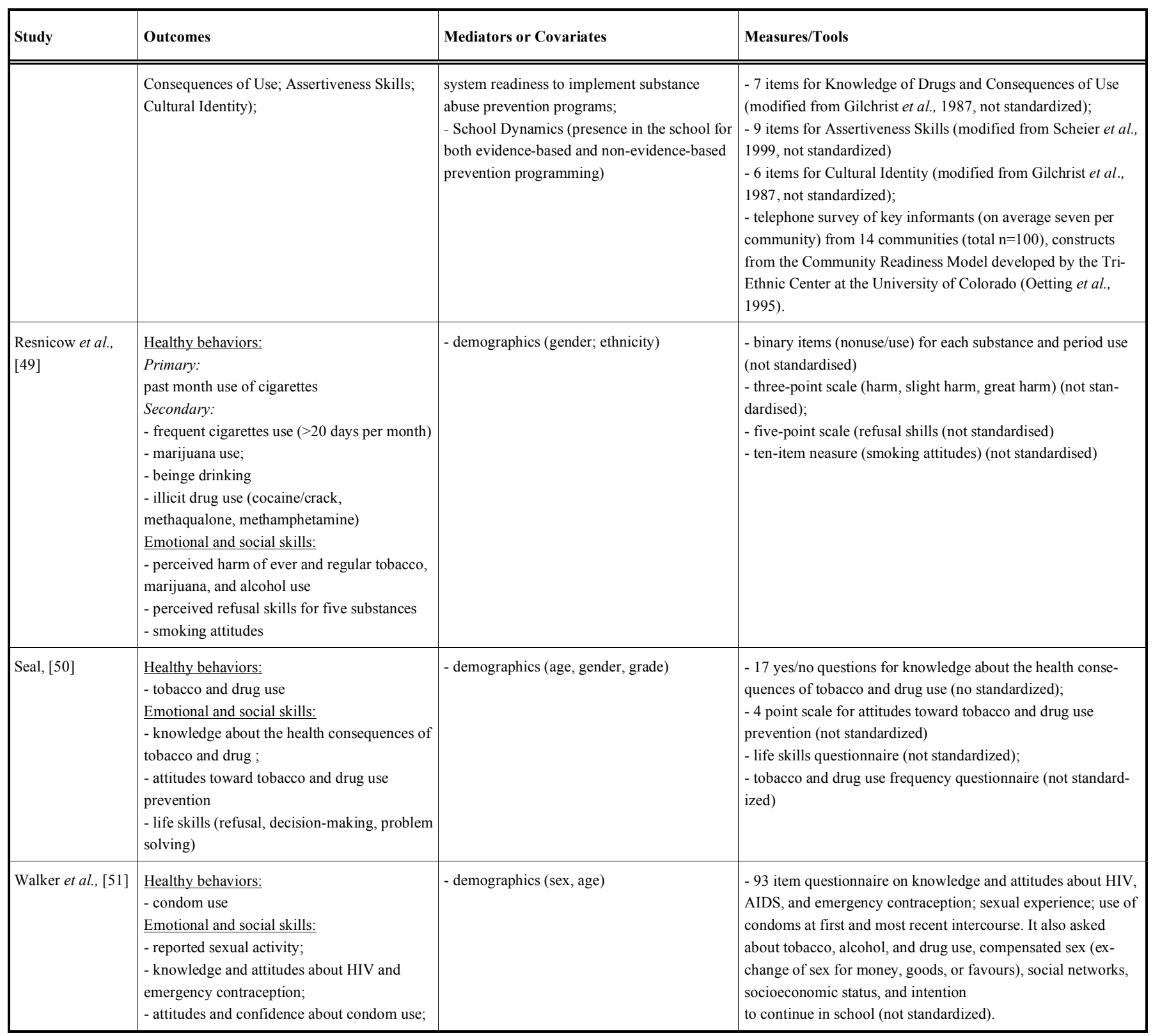

involved students and their teachers, but not their parents, the school environment and the community $[54,58,59,60]$. Finally, $1(1.4 \%)$ study involved students, their parents, the school environment and the community, but not their teachers [44 (study 1)], and 1 (1.4\%) study involved students and the school environment but not their parents, their teachers and the community [45].

No study involved students, their parents, their teachers, the school environment and their relevant community simultaneously.

Regarding the effectiveness of the included studies, findings were very heterogeneous about the outcomes assessed by different tools and statistical analyses. Table $\mathbf{3}$ summarises that Life Skills Training (LST) is generally effective in improving emotional and social skills, and healthy behaviours $[20,32,42,43,44$ (study 1 and 2), 46, 48-51, 56, 58], as well as other kinds of interventions on emotional and so- cial skills, psychological wellbeing, healthy behaviours, and academic performance, namely the "Gatehouse Project" [52], "Free fruit and vegetables snacks plus Enhanced Nutrition Education" [53], "Zippis' Friends" [47], "4Rs SocialEmotional Learning Program (Reading, Writing, Respect, Resolution)" [55], "Yoga Ed Program" [57], "Kripalu Yoga" [60], "COPE (Creating Opportunities for Personal Empowerment) Healthy Lifestyles TEEN (Thinking, Emotions, Exercise, Nutrition) Program" [59], "PATHS (Positive Adolescents Training through Holistic Social Programmes" [54], "Plan for Success Goal Clarification survey" [45].

\section{DISCUSSION}

This systematic review reports the main features of universal school-based RCTs aimed to enhance the youths' emotional and social skills in order to promote their positive development and wellbeing. Furthermore, it shows 
Table 2b. Outcomes and tools: "Life Skills Training" (LST) programs measuring only healthy behavior outcomes.

\begin{tabular}{|c|c|c|c|}
\hline Botvin et al., [32] & $\begin{array}{l}\text { - cocaine, inhalants, nonmedical pill use, } \\
\text { heroin and other narcotics, hallucinogens use } \\
\text { - tobacco, alcohol and marijuana use }\end{array}$ & $\begin{array}{l}\text { tobacco, alcohol and marijuana current use } \\
\text { (amount and frequency at baseline) }\end{array}$ & $\begin{array}{l}\text { Not standardized scales: } \\
-8 \text { point scale for tobacco' frequency use } \\
7 \text { point scale for tobacco'amount use } \\
9 \text { point scale for alcohol frequency use } \\
6 \text { point scale for alcohol amount use } \\
9 \text { point scale for frequency of getting drunk } \\
9 \text { point scale for frequency of marijuana use }\end{array}$ \\
\hline $\begin{array}{l}\text { Spoth } \text { et al., }[56] \\
\text { - see also: } \\
\text { Spoth } \text { et al., } \\
{[69 ; 70]}\end{array}$ & $\begin{array}{l}\text { - alcohol initiation (AI); } \\
\text { - cigarette initiation (CI); - marijuana initia- } \\
\text { tion (MI); } \\
\text { - monthly frequency of Alcohol Use (AF); } \\
\text { - monthly frequency of Cigarette Use (CF); } \\
\text { - monthly frequency of Drunkenness(DF); } \\
\text { - monthly frequency of Marijuana Use (MF); } \\
\text { - more problematic or serious substance use } \\
\text { (poly-substance use) }\end{array}$ & $\begin{array}{l}\text { - Sociodemographics (gender; ethnicity; living } \\
\text { with both biological parents; free or reduced- } \\
\text { price school lunch) }\end{array}$ & $\begin{array}{l}\text { - Substance Initiation Index - } 3 \text { item (not standardized); } \\
\text { - } 4 \text { item for substance frequency use (not standardized); } \\
\text { - Monthly poly-substance use, } 3 \text { items (MPU) index (not } \\
\text { standardized); } \\
\text { - advanced poly-substance use (APU) index, } 5 \text { items (not } \\
\text { standardized) }\end{array}$ \\
\hline $\begin{array}{l}\text { Spoth et al., } \\
\text { study } 1[44]\end{array}$ & - methamphetamine use & & 1 item (not standardized) \\
\hline $\begin{array}{l}\text { Spoth et al., } \\
\text { study } 2 \text { [44] }\end{array}$ & - methamphetamine use & & 2 item (not standardized) \\
\hline Young et al., [58] & $\begin{array}{l}\text { - Self-reported estimated daily energy } \\
\text { expenditure (physical activity), } \\
\text { - self-reported sedentary } \\
\text { activities (television viewing and computer } \\
\text { or Internet use), } \\
\text { - cardiorespiratory fitness } \\
\text { - cardiovascular disease risk factors (BMI, } \\
\text { waist-hip ratio, waist circumference, blod } \\
\text { pressure, total cholesterol level, lipopretein } \\
\text { level. }\end{array}$ & & $\begin{array}{l}\text { - 7-day Physical Activity Recall; } \\
\text { - submaximal 3-stage step test for cardiorespiratory fitness; } \\
\text { - selected outcome from a questionnaire for sedentary activities } \\
\text { (not standardized) } \\
\text { - standard methods for height, weight, waist and hip circumfer- } \\
\text { ence, blood pressure, } \\
\text { - venose blood test for total cholesterol and lipoprotein }\end{array}$ \\
\hline
\end{tabular}

Table 2c. Outcomes and tools: Different programs (than LST) on emotional and social skills, psychological wellbeing indicators, healthy behaviors, academic performance outcomes.

\begin{tabular}{|c|c|c|c|}
\hline Study & Outcomes & Mediators or Baseline Covariates & Measures/Tools \\
\hline Bond et al., [52] & $\begin{array}{l}\text { Psychological wellbeing indicators } \\
\text { - Mental health status (self reported anxi- } \\
\text { ety/depression); } \\
\text { - social relations (availability of attachments } \\
\text { and conflictual relationships); } \\
\text { - victimisation; } \\
\text { - school engagement } \\
\text { Healthy behavior } \\
\text { - substance use } \\
\text { - peers' substances use; }\end{array}$ & $\begin{array}{l}\text { - family structure (intact; separated/divorced; } \\
\text { other circumstances); language other than } \\
\text { English spoken at home; cowntry of birth } \\
\text { (Australia vs other); parents' smoking ciga- } \\
\text { rettes and/or drinking alcohol; } \\
\text { - gender }\end{array}$ & $\begin{array}{l}\text { - Clinical Interview Schedule-Revised (CIS-R) } \\
\text { - Interview Schedule for Social Interaction } \\
\text { - } 4 \text { items addressing types of recent victimisation; } \\
\text { - School Engagement Scale; } \\
\text { - set of questions developed by the Center for Adoleschent } \\
\text { Health (Patton et al., 1995) to rate current smoking and } \\
\text { drinking; } \\
\text { - } 7 \text { days diary for students who had smoking tobacco in the } \\
\text { past month or drunk alcohol in the past two weeks or used } \\
\text { marijuana in the past six months. }\end{array}$ \\
\hline He et al., [53] & $\begin{array}{l}\text { Healthy behavior } \\
\text { - fruit and vegetable consumption } \\
\text { Emotional and social skills } \\
\text { - knowledge, attitude, liking, self-efficay, } \\
\text { intention, willingness, habit, preferences and } \\
\text { peer influences toward fruit and vegetables }\end{array}$ & & $\begin{array}{l}\text { - Pre-Coded 24h Fruit and Vegetable Recall Questionnaire } \\
\text { (Haraldsdootir } \text { et al., 2005); } \\
\text { - Pro-Children Questionnaire (adapted) }\end{array}$ \\
\hline
\end{tabular}


(Table 2c.) contd....

\begin{tabular}{|c|c|c|c|}
\hline Holen et al., [47] & $\begin{array}{l}\text { Emotional and social skills } \\
\text { - coping strategies (distraction, social with- } \\
\text { drawal, cognitive restructuring, self-criticism, } \\
\text { blaming others, problem solving, emotional } \\
\text { expression, wishful thinking, social support, } \\
\text { resignation) } \\
\text { Psychological wellbeing indicators } \\
\text { - mental health (emotional symptoms, } \\
\text { conduct problems, hyperactivity/inattention, } \\
\text { perr problems, prosocial behaviors) }\end{array}$ & $\begin{array}{l}\text { - demographics (parents' socio-economic } \\
\text { status (SES); childs' sex) }\end{array}$ & $\begin{array}{l}\text { - Kidcope Questionnaire (Spirito et al., 1988) - children } \\
\text { version (7-12 years); } \\
\text { - adaptation of Kidcope questionnaire - adolescent version } \\
\text { (administered to parents) } \\
\text { - Strenghts and Difficulties Quationnaire (SDQ), (Goodman, } \\
\text { 1997) (parents and teachers form) }\end{array}$ \\
\hline Jones et al., [55] & $\begin{array}{l}\text { Emotional and social skills: } \\
\text { - Social-Cognitive Processes (hostile attribu- } \\
\text { tion biases; aggressive interpersonal negotia- } \\
\text { tion strategies; normative beliefs about } \\
\text { aggression); } \\
\text { - Aggressive and Prosocial Behaviors (child } \\
\text { aggression; child social competence); } \\
\text { Psychological wellbeing indicators } \\
\text { - Social-Emotional Symptomatology (child } \\
\text { ADHD symptoms; depressive symptoms; } \\
\text { aggressive and prosocial fantasies); } \\
\text { Academic performance: } \\
\text { - academic skills; } \\
\text { - math and reading achievement; } \\
\text { - attendance rate }\end{array}$ & $\begin{array}{l}\text { - household socioeconomic status (SES) risk } \\
\text { index (single-parent household; less than high } \\
\text { school education; poverty at or below } 100 \% \\
\text { of the federal poverty level; unemployment); } \\
\text { - Community risk; } \\
\text { - Child behavioral risk; } \\
\text { - Children' sociodemographics (gender; } \\
\text { race/ethnicity); } \\
\text { - teacher' burnout; } \\
\text { - teacher' experience; } \\
\text { - classroom size }\end{array}$ & $\begin{array}{l}\text { - } 2 \text { self-report questionnaires for hostile attribution biases and } \\
\text { aggressive interpersonal negotiation strategies (adapted from } \\
\text { the Home Interview Questionnaire (Dalhberg } \text { et al., 1998; } \\
\text { Dodge, 1986) } \\
\text { - Normative beliefs about Aggression Scale (Huesmann \& } \\
\text { Guerra, 1997) (self report); } \\
\text { - ADHD Symptomatology Scale (Milch } \text { et al., 1982) (teacher } \\
\text { report) for ADHD symptoms; } \\
\text { - Diagnostic Interview Schedule for Children Predictive Scales } \\
\text { (Lucas } \text { et al., 2001) (self-report) for depressive symptoms; } \\
\text { - “What I Think” (Rosenfeld } \text { et al., 1982) (self-report) for } \\
\text { aggressive and prosocial fantasies; } \\
\text { - Behavioral Assessment System for Children (Reynolds \& } \\
\text { Kamphaus, 1998) (teacher report) for child aggression and } \\
\text { conduct problems } \\
\text { - Social Competence Scale (CPPRG, 1999) (teacher report) for } \\
\text { child social competence; } \\
\text { - 9 items adapted from the Early Childhood Longitudinal } \\
\text { Study, Kindergarten (ECLS-K) for academic skills; } \\
\text { - New York State standardized assessment of math and reading } \\
\text { achievement (standard reports); } \\
\text { - NYC Department of Education standard reports for atten- } \\
\text { dance rate (school years 2004-2005; 2005-2006); } \\
\text { - parents' report for SES risk index } \\
\text { - parent report on the Community Risk and Resources } \\
\text { Questionnaire (Forehand et al., 2000); } \\
\text { - Teacher Burnout Inventory (Maslach } \text { et al., 1996) }\end{array}$ \\
\hline Khalsha et al., [57] & $\begin{array}{l}\text { Psychological wellbeing indicators } \\
\text { - personality (emotional symptoms, school } \\
\text { problems, internalizing problems, inatten- } \\
\text { tion/hyperactivity, personal adjustment, } \\
\text { anxiety, anger control, mania, ego strenght); } \\
\text { - mood states; } \\
\text { Emotional and social skills: } \\
\text { - resilience; } \\
\text { - perceived stress; } \\
\text { - Self-confidence during Stress; } \\
\text { - Life Purpose and Satisfaction }\end{array}$ & & $\begin{array}{l}\text { - Self-Report of Personality (SRP) version of the Behavior } \\
\text { assessment Survey for Children Version } 2 \text { (BASC-2) } \\
\text { - Profile of Mood States short form (POMS-SF); } \\
\text { - Resilience Scale (RS); } \\
\text { - Perceived Stress Scale (PSS); } \\
\text { - Inventory of Positive Psychological Attitudes-32R (IPPA) }\end{array}$ \\
\hline $\begin{array}{l}\text { Melnik et al., } \\
{[59]}\end{array}$ & $\begin{array}{l}\text { healthy behaviors } \\
\text { - phisical activity } \\
\text { - substance use (alcohol, marijuana); } \\
\text { academic performance } \\
\text { Psychological and physical wellbeing indica- } \\
\underline{\text { tors }} \\
\text { - depressive and anxiety symptoms; } \\
\text { - health grade } \\
\text { - overweight } \\
\text { - BMI } \\
\text { Emotional and social skills } \\
\text { - social skills (cooperation, assertion, aca- } \\
\text { demic competence); }\end{array}$ & - acculturation & $\begin{array}{l}\text { - pedometer steps; } \\
\text { - Healthy Lifestyles Behavior Scale (HLBS) (self report); } \\
\text { - Heights and Weights; } \\
\text { - Beck Youth Inventory II (self report); } \\
\text { - Social Skills Rating System (SSRS) (teacher report) } \\
\text { - questions about substances use from Youth Risk behavior } \\
\text { Survey (self report); } \\
\text { - students' health course grade (school records); } \\
\text { - acculturation, Habits, and Interests Multicultural Scale for } \\
\text { Adolescents (AHIMSA) (self report) }\end{array}$ \\
\hline
\end{tabular}


(Table 2c.) contd....

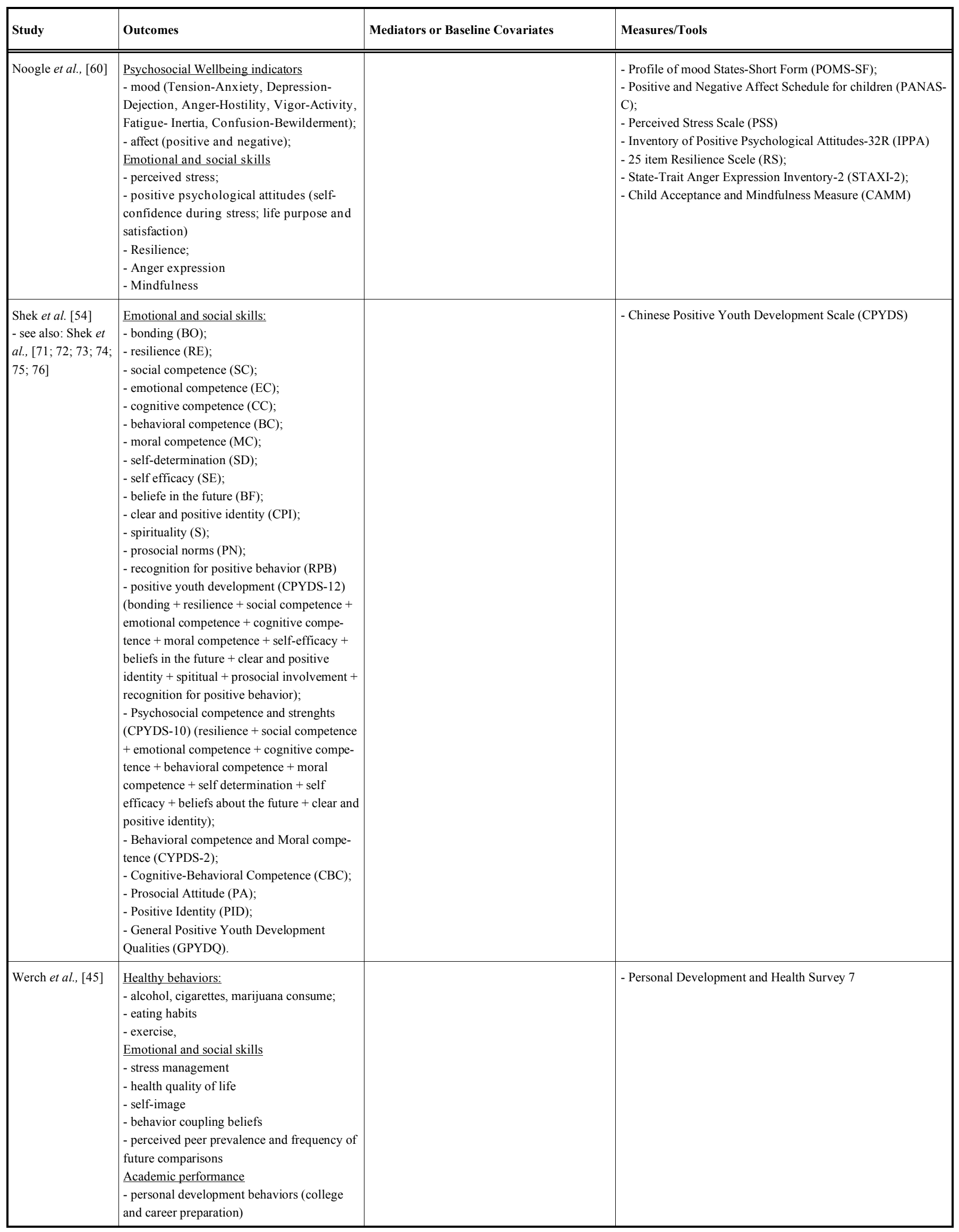


Table 3. Quality features of the studies included.

\begin{tabular}{|c|c|c|c|c|c|c|}
\hline Study & Standardized Measures & $\begin{array}{l}\text { Follow-up } \\
\geq 6 \\
\text { Months }\end{array}$ & $\begin{array}{l}\text { Waves of } \\
\text { Data } \geq 2 \\
\text { Academic } \\
\text { Year }\end{array}$ & $\begin{array}{l}\text { Effectiveness } \\
(\mathbf{p}<0.05)\end{array}$ & $\begin{array}{l}\text { Safe Practices } \\
3 \text { at least, } \\
\text { among: Sequency, } \\
\text { Active, Focused, } \\
\text { Explicit }\end{array}$ & $\begin{array}{l}\text { Whole School } \\
\text { Approach levels }\end{array}$ \\
\hline Bond et al., [52] & $\begin{array}{l}\text { YES (anxiety/depressive symptoms) } \\
\text { YES (social interactions) } \\
\text { NO (victimization) } \\
\text { YES (school engagement) } \\
\text { YES (cigarette and alchool use) }\end{array}$ & NO & YES & $\begin{array}{l}\text { YES (substance use) } \\
\text { NO (anxiety/depressive } \\
\text { symptoms; social and school } \\
\text { relationships) }\end{array}$ & YES & $\begin{array}{l}\text { YES (Students) } \\
\text { NO (Parents) } \\
\text { YES (Teachers) } \\
\text { YES (School environment) } \\
\text { NO (Community) }\end{array}$ \\
\hline Botvin et al., [32] & $\begin{array}{l}\text { YES (marijuana, cocaine, inhalants, } \\
\text { nonmedical pill use, heroin and other } \\
\text { narcotics, hallucinogens use) }\end{array}$ & NO & NO & $\begin{array}{l}\text { YES (marijuana; inhalants; heroin } \\
\text { and othe narcotics, hallucinogens } \\
\text { use) } \\
\text { NO (cocaine; non medical pill use) }\end{array}$ & YES & $\begin{array}{l}\text { YES (Students) } \\
\text { NO (Parents) } \\
\text { YES (Teachers) } \\
\text { YES (School environment) } \\
\text { NO (Community) }\end{array}$ \\
\hline Buhler et al., [46] & $\begin{array}{l}\text { NO (tobacco and alcohol use) } \\
\text { NO (affinity toward tobacco and alcohol) } \\
\text { NO (knowledge about life skills and life } \\
\text { skills behaviors; refusal assertiveness) }\end{array}$ & NO & NO & $\begin{array}{l}\text { YES (nicotine abuse) } \\
\text { NO (alcohol abuse) } \\
\text { YES (tobaco and alcohol affinity) } \\
\text { YES (knowledge skilled behav- } \\
\text { iors; life skills) } \\
\text { NO (Knowledge unskilled behav- } \\
\text { iors; life skills deficit) } \\
\text { YES (Knowledge skilled behav- } \\
\text { iors on all outcomes) } \\
\text { NO (life skills on tobacco and } \\
\text { alcohol affinity) } \\
\text { YES (life skills on nicotine abuse } \\
\text { in smokers at baseline) }\end{array}$ & YES & $\begin{array}{l}\text { YES (Students) } \\
\text { NO (Parents) } \\
\text { YES (Teachers) } \\
\text { YES (school environment) } \\
\text { NO (Community) }\end{array}$ \\
\hline $\begin{array}{l}\text { Eisen } \text { et al., [42] } \\
\text { - see also: } \\
\text { Eisen et al., [68] }\end{array}$ & $\begin{array}{l}\text { YES (tobacco, alcohol, illegal/illicit drugs } \\
\text { use) } \\
\text { YES (intention to use substance) } \\
\text { YES ( social influences) } \\
\text { YES (interpersonal perceptions) } \\
\text { YES (comunication skills) } \\
\text { YES (self efficacy) } \\
\text { YES (sensation-seeking) }\end{array}$ & NO & NO & $\begin{array}{l}\text { YES (marijuana' lifetime and 30- } \\
\text { day use) } \\
\text { NO (lifetime and 30-day use of } \\
\text { cigarettes, other illicit substances, } \\
\text { alcohol; last 30-day binge drink- } \\
\text { ing) } \\
\text { YES (refusal self efficacy for } \\
\text { alcohol and marijuana) } \\
\text { NO (intention, perceived harm } \\
\text { perceived peer use/close friend for } \\
\text { all substance; refusal self efficacy } \\
\text { for cigarettes and cocaine) }\end{array}$ & YES & $\begin{array}{l}\text { YES (Students) } \\
\text { NO (Parents) } \\
\text { YES (Teachers) } \\
\text { YES (school environment) } \\
\text { NO (Community) }\end{array}$ \\
\hline $\begin{array}{l}\text { Fitzpatrick et al., } \\
{[20]}\end{array}$ & $\begin{array}{l}\text { YES (prosocial behavior; emotional and } \\
\text { behavioral difficulties; active coping/less } \\
\text { use of avoidance) } \\
\text { NO (help seeking; view of school social } \\
\text { environment) }\end{array}$ & YES & NO & $\begin{array}{l}\text { YES (in the enhanced (EP) } \\
\text { intervention whole group for peer } \\
\text { problems; at risk EP boys for } \\
\text { emotional and behavioral difficul- } \\
\text { ties, hyperactivity and total } \\
\text { difficulties) } \\
\text { NO (EP for coping strategies) } \\
\text { YES (in the standard intervention } \\
\text { (SP) group for help seeking) }\end{array}$ & $\begin{array}{l}\text { Both EP and SP } \\
\text { interventions: } \\
\text { YES }\end{array}$ & $\begin{array}{l}\text { Both EP and SP interven- } \\
\text { tions: } \\
\text { YES (Students) } \\
\text { NO (Parents) } \\
\text { YES (Teachers) } \\
\text { YES (school environment) } \\
\text { YES (Community) }\end{array}$ \\
\hline He et al., [53] & $\begin{array}{l}\text { YES (fruit and vegetable consumption) } \\
\text { YES (knowledge, attitude, liking, self- } \\
\text { efficay, intention, willingness, habit, } \\
\text { preferences and peer influences toward } \\
\text { fruit and vegetables) }\end{array}$ & NO & NO & $\begin{array}{l}\text { Yes YES (in FFVS+ENE inter- } \\
\text { vention for fruit and vegetables } \\
\text { consumption at school) } \\
\text { NO (in FFVS+ENE intervention } \\
\text { for fruit and vegetables consump- } \\
\text { tion at home) } \\
\text { YES (in FFVS+ENE intervention } \\
\text { for liking toward fruit and vegeta- } \\
\text { bles) } \\
\text { YES (adverse outcome in FFVS } \\
\text { intervention: unfavorable change } \\
\text { in self efficacy, intention and peer } \\
\text { influence in vegetable consump- } \\
\text { tion }\end{array}$ & $\begin{array}{l}\text { FFVS+ENE } \\
\text { intervention: } \\
\text { YES }\end{array}$ & $\begin{array}{l}\text { FFVS+ENE intervention: } \\
\text { YES (Students) } \\
\text { NO (Parents) } \\
\text { YES (Teachers) } \\
\text { YES (school environment) } \\
\text { YES (Community) }\end{array}$ \\
\hline
\end{tabular}


(Table 3) contd....

\begin{tabular}{|c|c|c|c|c|c|c|}
\hline Study & Standardized Measures & $\begin{array}{l}\text { Follow-up } \\
\geq 6 \\
\text { Months }\end{array}$ & $\begin{array}{l}\text { Waves of } \\
\text { Data } \geq 2 \\
\text { Academic } \\
\text { Year }\end{array}$ & $\begin{array}{l}\text { Effectiveness } \\
(p<0.05)\end{array}$ & $\begin{array}{l}\text { Safe Practices } \\
3 \text { at least, } \\
\text { among: Sequency, } \\
\text { Active, Focused, } \\
\text { Explicit }\end{array}$ & $\begin{array}{l}\text { Whole School } \\
\text { Approach levels }\end{array}$ \\
\hline Holen et al., [47] & $\begin{array}{l}\text { YES (coping strategies) } \\
\text { YES (mental health: emotional symptoms; } \\
\text { conduct problems; hyperactiv- } \\
\text { ity/inattention; peer problems, prosocial } \\
\text { behaviors) }\end{array}$ & NO & NO & $\begin{array}{l}\text { YES (children and parents for } \\
\text { coping strategies: children for } \\
\text { oppositional strategies; parents for } \\
\text { active and support seeking strate- } \\
\text { gies) } \\
\text { NO (parents and teachers for } \\
\text { emotional symptoms; conduct } \\
\text { problems; hyperactiv- } \\
\text { ity/inattention; peer problems, } \\
\text { prosocial behaviors) } \\
\text { YES (teachers for impact of } \\
\text { mental health problems) }\end{array}$ & YES & $\begin{array}{l}\text { YES (Students) } \\
\text { NO (Parents) } \\
\text { YES (Teachers) } \\
\text { YES (school environment) } \\
\text { NO (Community) }\end{array}$ \\
\hline Huang et al., [48] & $\begin{array}{l}\text { NO (intention, attitude, subjective norm, } \\
\text { perceived behavioral control about drug } \\
\text { use) } \\
\text { NO (life skills) }\end{array}$ & NO & NO & $\begin{array}{l}\text { YES (in LST group for life skills } \\
\text { and attitude, subjective norm, } \\
\text { perceived behavioral control, } \\
\text { intention about drug use) }\end{array}$ & YES & $\begin{array}{l}\text { YES (Students) } \\
\text { NO (Parents) } \\
\text { YES (Teachers) } \\
\text { YES (school environment) } \\
\text { NO (Community) }\end{array}$ \\
\hline Johnson et al., [43] & $\begin{array}{l}\text { NO (Harmfull Legal Products (HLP) use } \\
\text { in the past } 30 \text { days: inhalants, prescription } \\
\text { medicines, over-the-counter medications, } \\
\text { common household products) } \\
\text { NO (substance use in the past } 30 \text { days: } \\
\text { tobacco, alcohol, marijuana or hashish) } \\
\text { NO (Risk factors: Peer Use of HLPs; Peer } \\
\text { Normative Beliefs about HLPs); } \\
\text { NO (Protective factors: Knowledge of } \\
\text { Drugs and Consequences of Use; Asser- } \\
\text { tiveness Skills; Cultural Identity); }\end{array}$ & YES & NO & $\begin{array}{l}\text { YES (harmful legal products, } \\
\text { inhalants the most) } \\
\text { NO (tobacco, alcohol, marijuana) } \\
\text { NO (risk and protective factors on } \\
\text { substance use) }\end{array}$ & YES & $\begin{array}{l}\text { YES (Students) } \\
\text { NO (Parents) } \\
\text { YES (Teachers) } \\
\text { YES (school environment) } \\
\text { NO (Community) }\end{array}$ \\
\hline Jones et al., [55] & $\begin{array}{l}\text { YES (Social-Cognitive Processes: hostile } \\
\text { attribution biases; aggressive interpersonal } \\
\text { negotiation strategies; normative beliefs } \\
\text { about aggression) } \\
\text { YES (Social-Emotional Symptomatology: } \\
\text { child ADHD symptoms; depressive } \\
\text { symptoms; aggressive and prosocial } \\
\text { fantasies) } \\
\text { YES (Aggressive and Prosocial Behaviors: } \\
\text { child aggression; child social competence) } \\
\text { YES (Academic Performance: academic } \\
\text { skills; math and reading achievement; } \\
\text { attendance rate) }\end{array}$ & NO & YES & $\begin{array}{l}\text { YES (social-cognitive processes } \\
\text { and social-emotional symptoma- } \\
\text { tology) } \\
\text { YES (aggressive and socially } \\
\text { competent behavior) } \\
\text { No (main effect for academic } \\
\text { functioning) } \\
\text { YES (chidren at behavioral risk at } \\
\text { baseline for academic functioning: } \\
\text { maths and reading achievement) } \\
\text { NO (chidren at behavioral risk at } \\
\text { baseline for social and emotional } \\
\text { skills) }\end{array}$ & YES & $\begin{array}{l}\text { YES (Students) } \\
\text { NO (Parents) } \\
\text { YES (Teachers) } \\
\text { YES (school environment) } \\
\text { NO (Community) }\end{array}$ \\
\hline Khalsha et al., [57] & $\begin{array}{l}\text { YES (emotional symptoms, school prob- } \\
\text { lems, internalizing problems, inatten- } \\
\text { tion/hyperactivity, personal adjustment, } \\
\text { anxiety, anger control, mania, ego } \\
\text { strenght); } \\
\text { YES (mood states); } \\
\text { YES (resilience); } \\
\text { YES (perceived stress); } \\
\text { YES (Self-confidence during Stress); } \\
\text { YES (Life Purpose and Satisfaction) }\end{array}$ & NO & NO & $\begin{array}{l}\text { YES (anger control, fatigue, } \\
\text { resilience) } \\
\text { NO (emotional symptoms, school } \\
\text { problems, internalizing problems, } \\
\text { inattention/hyperactivity, personal } \\
\text { adjustment, anxiety, mania, ego } \\
\text { strenght, mood states, self- } \\
\text { confidence during stress, life } \\
\text { purpose and satisfation) }\end{array}$ & YES & $\begin{array}{l}\text { YES (Students) } \\
\text { NO (Parents) } \\
\text { NO (Teachers) } \\
\text { NO (school environment) } \\
\text { NO (Community) }\end{array}$ \\
\hline Melnyk et al., [59] & $\begin{array}{l}\text { YES (healthy lifestyles behaviors: physical } \\
\text { activity) } \\
\text { YES (health grade) } \\
\text { YES (overweight) } \\
\text { YES (BMI) } \\
\text { YES (depressive and anxiety symptoms); } \\
\text { YES (social skills:cooperation, assertion, } \\
\text { academic competence); } \\
\text { YES substance use (alcohol, marijuana); } \\
\text { YES academic performance }\end{array}$ & YES & NO & $\begin{array}{l}\text { YES (physical activity; BMI; } \\
\text { social skills: coperation, as- } \\
\text { sertetion, academic performance; } \\
\text { health grade; substance use } \\
\text { (alcohol); overweight) } \\
\text { NO (substance use: marijuana; } \\
\text { anxiety and depressive symptoms) }\end{array}$ & YES & $\begin{array}{l}\text { YES (Students) } \\
\text { NO (Parents) } \\
\text { YES (Teachers) } \\
\text { NO (school environment) } \\
\text { NO (Community) }\end{array}$ \\
\hline
\end{tabular}


(Table 3) contd....

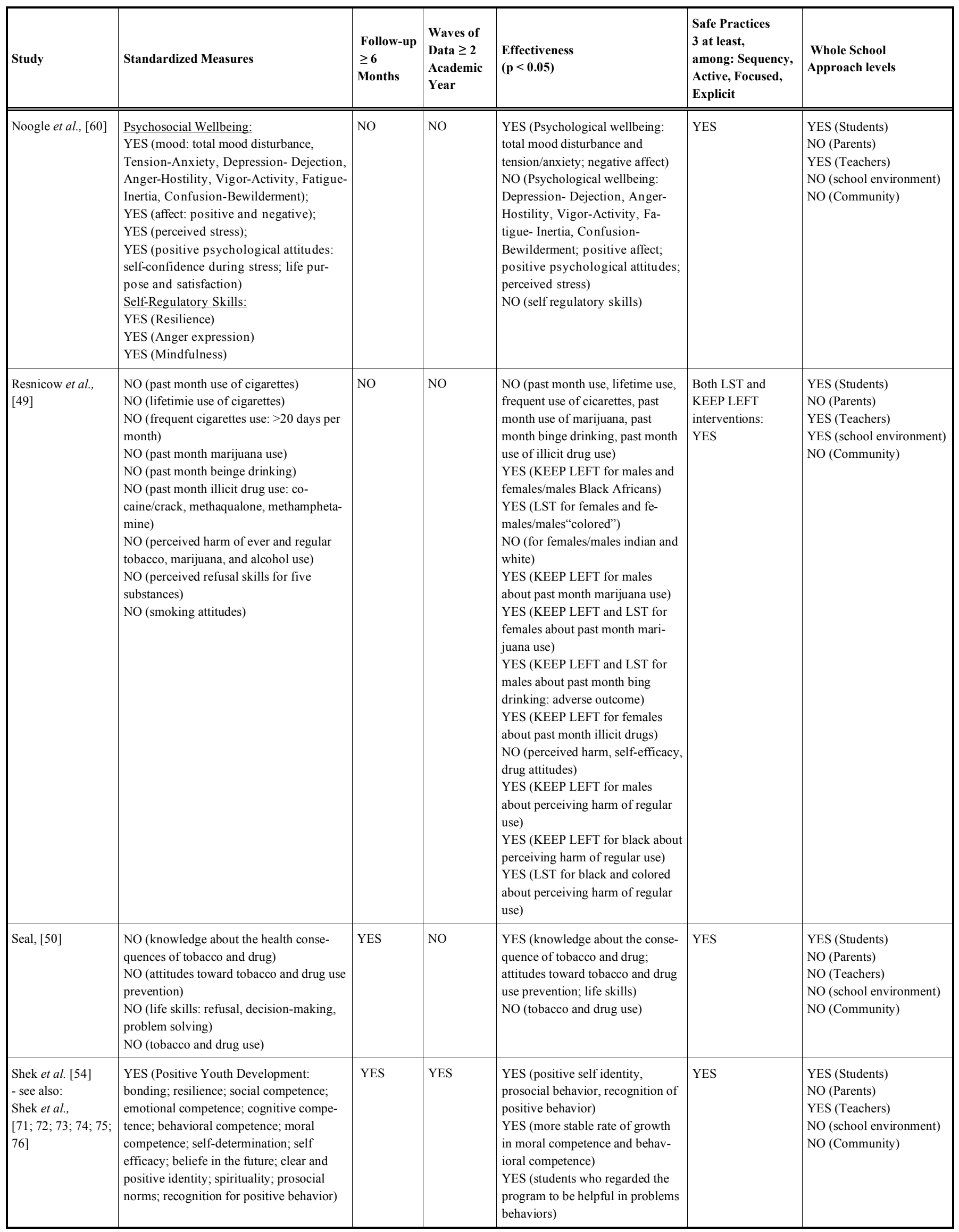


(Table 3) contd....

\begin{tabular}{|c|c|c|c|c|c|c|}
\hline Study & Standardized Measures & $\begin{array}{l}\text { Follow-up } \\
\geq 6 \\
\text { Months }\end{array}$ & $\begin{array}{l}\text { Waves of } \\
\text { Data } \geq 2 \\
\text { Academic } \\
\text { Year }\end{array}$ & $\begin{array}{l}\text { Effectiveness } \\
(\mathbf{p}<0.05)\end{array}$ & $\begin{array}{l}\text { Safe Practices } \\
3 \text { at least, } \\
\text { among: Sequency, } \\
\text { Active, Focused, } \\
\text { Explicit }\end{array}$ & $\begin{array}{l}\text { Whole School } \\
\text { Approach levels }\end{array}$ \\
\hline $\begin{array}{l}\text { Spoth et al., } \\
\text { study } 1[44]\end{array}$ & NO (past year methamphetamine use) & YES & YES & $\begin{array}{l}\text { YES (ISFP for past year methan- } \\
\text { phetamine use) } \\
\text { NO (PDFY for past year methan- } \\
\text { phetamine use) }\end{array}$ & $\begin{array}{l}\text { Both PDFY and } \\
\text { ISFP: } \\
\text { YES }\end{array}$ & $\begin{array}{l}\text { Both PDFY and ISFP: } \\
\text { YES (Students) } \\
\text { YES (Parents) } \\
\text { NO (Teachers) } \\
\text { YES (school environment) } \\
\text { YES (Community) }\end{array}$ \\
\hline $\begin{array}{l}\text { Spoth et al., } \\
\text { study } 2[44]\end{array}$ & $\begin{array}{l}\text { NO (past year and lifetime methampheta- } \\
\text { mine use) }\end{array}$ & YES & YES & $\begin{array}{l}\text { YES (LST+SFP 10-14 for lifetime } \\
\text { use) } \\
\text { YES (LST only for lifetime use) }\end{array}$ & $\begin{array}{l}\text { Both LST and SFP } \\
10-14: \\
\text { YES }\end{array}$ & $\begin{array}{l}\text { For SFP 10-14 see ISFP in } \\
\text { previews row; } \\
\text { LST: } \\
\text { YES (Students) } \\
\text { NO (Parents) } \\
\text { YES (Teachers) } \\
\text { YES (school environment) } \\
\text { NO (Community) }\end{array}$ \\
\hline $\begin{array}{l}\text { Spoth et al., }[56] \\
\text { - see also: } \\
\text { Spoth } \text { et al., } \\
{[69 ; 70]}\end{array}$ & $\begin{array}{l}\text { NO (alcohol, cigarettes, marijuana initia- } \\
\text { tion) } \\
\text { NO (monthly frequency of Alcohol, } \\
\text { Drunkenness Cigarette Marijuana Use ) } \\
\text { NO (more problematic or serious sub- } \\
\text { stance use: poly-substance use) }\end{array}$ & YES & YES & $\begin{array}{l}\text { YES (one or both interventions on } \\
\text { all substance initiation and for } \\
\text { polysubstance use in higher risk } \\
\text { subsamples) } \\
\text { YES (accumulation one or both } \\
\text { interventions benefits on out- } \\
\text { comes) }\end{array}$ & $\begin{array}{l}\text { Both LST and SFP } \\
\text { 10-14: } \\
\text { YES }\end{array}$ & $\begin{array}{l}\text { For SFP 10-14 see ISFP in } \\
\text { previews row; } \\
\text { LST: } \\
\text { YES (Students) } \\
\text { NO (Parents) } \\
\text { YES (Teachers) } \\
\text { YES (school environment) } \\
\text { NO (Community) }\end{array}$ \\
\hline Walker et al., [51] & $\begin{array}{l}\text { NO (condom use, reported sexual } \\
\text { Activity, knowledge and attitudes about } \\
\text { HIV and emergency contraception, atti- } \\
\text { tudes and confidence about condom use) }\end{array}$ & YES & NO & $\begin{array}{l}\text { NO (condom use) } \\
\text { YES (both intervention on knowl- } \\
\text { edge of HIV) } \\
\text { YES (LST + emergency contra- } \\
\text { ception on knowledge of emer- } \\
\text { gency contraception) } \\
\text { YES (both intervention on sexual } \\
\text { behaviors) }\end{array}$ & $\begin{array}{l}\text { Both LST and LST } \\
+ \text { emergency } \\
\text { contraception } \\
\text { YES }\end{array}$ & $\begin{array}{l}\text { Both LST and LST + } \\
\text { emergency contraception } \\
\text { YES (Students) } \\
\text { NO (Parents) } \\
\text { YES (Teachers) } \\
\text { YES (school environment) } \\
\text { NO (Community) }\end{array}$ \\
\hline Young et al., [58] & $\begin{array}{l}\text { YES Self-reported estimated daily energy } \\
\text { expenditure (physical activity), } \\
\text { NO self-reported sedentary } \\
\text { activities (television viewing and computer } \\
\text { or Internet use), } \\
\text { YES cardiorespiratory fitness } \\
\text { YES cardiovascular disease risk factors } \\
\text { (BMI, waist-hip ratio, waist circumfer- } \\
\text { ence, blod pressure, total cholesterol level, } \\
\text { lipopretein level) }\end{array}$ & NO & NO & $\begin{array}{l}\text { YES (spending more physical } \\
\text { education class time in moderate } \\
\text { to vigouros activity) } \\
\text { NO (daily energy expenditure, } \\
\text { moderate, hard or very hard } \\
\text { intensity expenditure, ) } \\
\text { YES (self-reported sedentary } \\
\text { activities) } \\
\text { YES (both interventions on } \\
\text { cardiorespiratory fitness) }\end{array}$ & YES & $\begin{array}{l}\text { YES (Students) } \\
\text { NO (Parents) } \\
\text { YES (Teachers) } \\
\text { NO (school environment) } \\
\text { NO (Community) }\end{array}$ \\
\hline
\end{tabular}

promising findings about the effectiveness of such interventions on the outcomes considered by the authors.

The studies included went openly beyond a problemfocused approach to embrace a more positive view of mental health to promote youths' wellbeing $[1,3,8]$. Collectively, these findings build on the positive results reported by other systematic reviews examining the promotion of positive development and wellbeing of children and teenagers in schools [9-12, 18, 22, 41].

Due to the variety in age/school grade of participants, characteristics of intervention and control groups, duration of programs and follow-up, assessed outcome and relevant 
tools, a direct comparison among the included studies is very difficult.

Overall, the interventions targeted social and emotional competences and attitudes about oneself, the others and the school. The main aim of these interventions was enhancing these skills and/or the healthy behaviours of the students (i.e. to prevent substance abuse) and/or promoting their psychological wellbeing (i.e. regarding mood and affects) and/or improving their academic performance.

While only small percentages of the included studies collected data at $\geq 6$ month follow-up after the end of the intervention $(40.9 \%)$ or during at least two academic years by repeated measures $(27.3 \%)$, the effects remained statistically significant by the time they were assessed. However, many included studies compared the groups exposed to such interventions to groups exposed to any kind of intervention. or treatment as usual (i.e. curricular health education).

This systematic review differs in emphasis from previous research syntheses by including exclusively universal school-based RCTs aimed to test the effectiveness of interventions focused on emotional and social skills improvement to promote the youths' wellbeing.

Noteworthy, among the texts excluded from this review, 15 papers described RCTs in this field with data analysis still pending. However, even if the researchers are increasingly attempting to conduct studies with rigorous experimental design, there is a range of practical and human impediments to using a "full" controlled randomisation in the school setting, such as objections from line staff and parents who feel that random assignment excludes some children having the same needs, and issues of access to parental consent or permission [12].

Furthermore, the studies included in this review aimed at a whole-school approach that promote "bottom-up" principles such as empowerment, autonomy, participation [3], and non-prescriptive and flexible practices that emphasize the need of end-user involvement. These features could contrast basically with manualized approaches that contain strict requirements for program fidelity, hard outcomes and measurable changes [10].

In this sense, the effectiveness of the RCTs included in this review may be relative in statistical terms, but it represents effects of outcomes that are important in the real world, are relatively large and similar to, or higher in, magnitude than those obtained by many other established preventive and treatment interventions in the fields of social sciences and medicine $[9,22,61]$.

As Weare et al. [10] already pointed out, many reviews of school-based interventions state that the acquisition of social and emotional skills was associated with a wide range of important health outcomes in the youth, including: positive youth development, character education, a reduction in depression and anxiety, conduct disorders, violence, bullying, conflict, and anger. This amount of data allows considering emotional and social skills improvement as an outcome in itself [10].

In this review, emotional and social skills were assessed as unique outcomes in two studies implementing Life Skills
Training (LST) specifically [20, 48], and in one study implementing a different program than LST [55]. Three more studies implementing different programs than LST assessed emotional and social skills as outcomes together with psychological wellbeing indicators $[47,52,57,60]$.

On the other hand, 5 out the 13 studies implementing LST evaluated only healthy behavior outcomes without assessing emotional and social skills as neither outcomes or mediators 32; 44 (study 1 and 2); 56; 58]. This choice could be due in part to the amount of evidence about the above mentioned association between life skills and health outcome improvement. At the same time, it marks a series of methodological issues and limits.

While healthy behaviors and academic performance are relatively easy to assess by specific indicators, some constructs such as positive youth development, the youths' psychological wellbeing and life skills are difficult to define univocally $[8 ; 12]$. Not surprisingly, many studies included in this review use no standardised measures, because their authors developed ad hoc measures to assess emotional and social skills and psychological wellbeing, as outcomes or mediators. This is probably due in part to the uncertain definition of these constructs, but also to the lack of studies aiming to develop and validate instruments that may assess the life skills and psychological wellbeing of the youth $[9,10$, $12,18,41,62]$.

Regarding the included studies that use standard tools, these constructs were measured by a single tool for each skill (i.e. Resilience Scale [63] to assess resilience in the study by Khalsha et al. [57]; Kidcope Questionnaire [64] to assess coping strategies in the study by Holen et al. [47]). Noteworthy some included studies $[46,54]$ attempted to build some tools to assess life skills or positive youth development but showed some limits, mainly concerning the validity tests on such tools (i.e. internal reliability and construct validity).

In this sense, the effectiveness of Life Skills Training (LST) as well as of other kinds of intervention on outcomes such as healthy lifestyle behaviours, academic performance, psychological wellbeing, with or without assessment of emotional and social skills reliably (see Tables $\mathbf{1 b}, \mathbf{2 b}$, and $\mathbf{3}$ ), is a critical point. Other variables than life skills could affect findings. These issues regard also those studies where the mediation effects of social and emotional skills on the main outcomes were postulated but not tested.

Another important finding of the current review is that in most of the included studies, classroom teachers effectively conducted programs to enhance their students' emotional and social skills and promote their wellbeing. Only in two included studies was the intervention implemented by external personnel, specialized in yoga techniques [57] and career coaching [45]. Therefore, this kind of interventions can be part of the routine educational practices and require external specialized personnel for teachers' training only.

Furthermore, the programs addressed to enhance the emotional and social skills of the young and promote their wellbeing are effective at all educational levels (elementary, middle, and high school).

As already emphasized by other authors $[9,10,12,18$, 41], the SAFE practices (Sequential, Active, Focused, Ex- 
plicit) and a whole-school approach moderate positive student's outcomes and distinguish evidence-based interventions in the school setting.

In this review, all the included studies contained no less than three SAFE practices considered as dichotomous variables "present/absent". Even if it could be preferable to evaluate SAFE practices as continuous variables $[9,65]$, we did not examine them this way due to the lack of information in the included study reports. Further research is needed to establish which SAFE practice impacts specifically on student outcomes, especially on their emotional and social skills. Some SAFE practices, in fact, may be more important than others depending on the nature and the number of evaluated outcomes, the age of students and their development stage, but also on ecological features, such as the school ethos and environment.

Furthermore, previous research pointed out that to achieve optimal impact, the work on personal skills need to be embedded within a whole-school, multi-component approach which includes changes to school ethos, teacher training, liaison with parents, parenting education, community involvement $[10,18]$. Most of the studies included in this review regard multi-component interventions targeted at no less than two of the following subjects: students, parents, teachers, school environment, and community.

However, only three RCTs included in this review [44 (study 1 and 2), 56] involved parents in the interventions tested. In the study 1 by Spoth et al. [44] and in two more included studies $[16,54]$ also the community was involved. From an ecological and systemic point of view, when interventions in the school setting are combined with efforts to create environmental support and reinforcement from family members, health professionals, other concerned community members, and the media, there is an increased likelihood that students will adopt positive social and health practices [20, $40,53,66,67]$.

\section{LIMITATIONS}

This systematic review was performed by searching in the Pubmed/Medline database only. Other databases, such as PsycInfo/Ovid, could provide more findings about schoolbased RCTs.

More school-based RCTs could be found by searching among the references of the studies included in the systematic review as well as in the excluded papers, reviews and/or meta-analyses.

\section{CONFLICT OF INTEREST}

The authors confirm that this article content has no conflict of interest.

\section{ACKNOWLEDGEMENTS}

Declared none.

\section{REFERENCES}

[1] WHO. Mental health action plan 2013-2020. Geneva: WHO Document Production Services 2013.

[2] Lindert J, von Ehrenstein OS, Grashow R, et al. Sexual and physical abuse in childhood is associated with depression and anxiety over the life course: Systematic review and meta-analysis. Int J Public Health 2014; 59(2): 359-72.

[3] WHO. Promoting Health through Schools. Geneva: WHO Technical Report Series 870; 1997a.

[4] WHO Regional Office for Europe. Regional guidelines: Development of health-promoting schools: A framework for action. Manila: WHO Regional Office for the Western Pacific 1996.

[5] Carta MG, Kovess V, Hardoy MC, et al. Psychosocial wellbeing and psychiatric care in the European Communities: Analysis of macro indicators. Soc Psychiatry Psychiatr Epidemiol 2004; 39(11): 883-92.

[6] Hardoy MC, Carta MG, Marci AR, et al. Exposure to aircraft noise and risk of psychiatric disorder: the Elmas survey. Soc Psychiatry Psychiatr Epidemiol 2005; 40(1): 24-6.

[7] Frankenburg W. Early identification of children at risk: Resiliency factors in prediction. $5^{\text {th }}$ International Conference, Denver: University of Colorado 1987.

[8] WHO. Life skills education in schools. Geneva: WHO/MNH/PSF/93.7A.Rev.2; 1997b.

[9] Durlak JA, Weissberg RP, Dymnicki AB, et al. The impact of enhancing students' social and emotional learning: A meta-analysis of school-based universal interventions. Child Dev 2011; 82: 40532.

[10] Weare K, Nind M. Mental health promotion and problem prevention in schools: What does the evidence say? Health Promot Int 2011; 26 (Suppl 1): 29-69.

[11] Stewart-Brown S. What is the evidence on school health promotion in improving health or preventing disease and, specifically, what is the effectiveness of the health promoting schools approach? Copenhagen: WHO Regional Office for Europe 2006. Available from: http://www.euro.who.int/document/e88185.pdf

[12] Catalano RF, Berglund ML, Ryan J, et al. Positive youth development in the United States: Research findings on evaluations of positive youth development programs. Ann Am Acad Pol Soc Sci 2004; 591: 98-124.

[13] Mura G, Rocha NBF, Helmich I, et al. Physical activity interventions in schools for improving lifestyle in European countries. Clin Pract Epidemiol Ment Health 2015; 11: 77-101.

[14] Cossu G, Cantone E, Pintus M, Pintus E, et al. Integrating children with psychiatric problems in the classroom. A systematic review. Clin Pract Epidemiol Ment Health 2015; 11: 41-57.

[15] Cantone E, Piras AP, Vellante M, et al. Interventions on bullying and cyberbullying in schools: A systematic review. Clin Epidemiol Ment Health 2015; 11: 58-76.

[16] Carta MG; Di Fiandra T; Rampazzo L, et al. Introduction. An overview of international literature on school interventions for promoting children and adolescents' mental health and well-being. Clin Pract Epidemiol Ment Health 2015; 11: 16-20.

[17] Tobler NS, Roona MR, Ochshorn P, et al. School-based adolescent drug prevention programs: 1998 meta-analysis. J Prim Prev 2000; 30: 275-336.

[18] Greenberg MT, Weissberg RP, O'Brien MU, et al. Enhancing school-based prevention and youth development through coordinated social, emotional and academic learning. Am Psychol 2003; 58(6-7): 466-74.

[19] Weare K, Murray M. Building a sustainable approach to mental health work in schools. Int J Ment Health Promot 2004; 6: 53-9.

[20] Fitzpatrick C, Conlon A, Cleary D, et al. Enhancing the mental health promotion component of a health and personal development programme in Irish schools. Adv Sch Ment Health Promot 2013; 6(2): 122-38.

[21] Bond LA, Hauf AMC. Taking stock and putting stock in primary prevention: characteristics of effective programs. J Prim Prev 2004; 24: 199-221.

[22] Durlak JA, Wells AM. Primary prevention mental health programs for children and adolescents: A meta-analytic review. Am J Community Psychol 1997; 25: 115-52.

[23] Dusenbury L, Falco M. Eleven components of effective drug abuse prevention curricula. J Sch Health 1995; 65: 420-5.

[24] Gresham FM. Best practices in social skills training. In: Thomas A, Grimes J, Eds. Best practices in school psychology. $3^{\text {rd }}$ ed. Washington DC: National Association of School Psychologists 1995: pp. 1021-30.

[25] Bradshaw CP, Brown JS, Hamilton SF. Bridging positive youth development and mental health services for youth with serious behaviour problems. Child Youth Care Forum 2008; 37: 209-26. 
[26] Bradshaw CP, Goldweber A, Fishbein D, Greenberg MT. Infusing developmental neuroscience into school-based preventive interventions: implications and future directions. J Adolesc Health 2012; 51(Suppl 2): 41-7.

[27] Hamilton M, Hamilton S. The youth development handbook: Coming of age in American communities. Thousand Oaks, CA: Sage Publications 2004.

[28] Damon W, Bonk KC, Menon J. Youth sense of purpose. In: What are the key indicators of positive youth development? A innovative session. Meeting of the Society for Research on Adolescence, Baltimore: Maryland 2004.

[29] Foxcroft DR, Tsertsvadze A. Universal school-based prevention programs for alcohol misuse in young people. Cochrane Database Syst Rev 2011; 11(5): CD009113.

[30] Hansen WB. School-based substance abuse prevention: A review of the state of the art in curriculum, 1980-1990. Health Educ Res 1992; 7(3): 403-30.

[31] Yankah E, Aggleton P. Effects and effectiveness of life skills education for HIV prevention in young people. AIDS Educ Prev 2008; 20(6): 465-85.

[32] Botvin GJ, Griffin KW, Diaz T, et al. Preventing illicit drug use in adolescents: Long-term follow-up data from a randomized control trial of a school population. Addict Behav 2000; 25(5): 769-74.

[33] Botvin GJ, Baker E, Dusenbury L, et al. Long-term follow-up results of a randomized drug abuse prevention trial in a white middle-class population. J Am Med Assoc 1995; 273(14): 1106-12.

[34] Pentz MA, Dwyer JH, MacKinnon DP, et al. A multi-community trial for primary prevention of adolescent drug abuse. J Am Med Assoc 1989; 261: 3259-66.

[35] Elias MJ, Zins JE, Weissberg RP, et al. Promoting social and emotional learning: Guidelines for educators. Alexandria, VA: Association for Supervision and Curriculum Development 1997.

[36] Benson PL. All kids are our kids: What communities must do to raise caring and responsible children and adolescents. $2^{\text {nd }}$ ed. San Francisco: Jossey-Bass 2006.

[37] Guerra NG, Bradshaw CP. Linking the prevention of problem behaviors and positive youth development: Core competencies for positive youth development and risk prevention. New Dir Child Adolesc Dev 2008; 122: 1-17.

[38] Weissberg RP, Kumpfer K, Seligman MEP. Prevention that works for children and youth: An introduction. Am Psychol 2003; 58: 425-32.

[39] Collaborative for academic, social, and emotional learning. safe and sound: An educational leader's guide to evidence-based social and emotional learning (SEL) programs. Chicago, IL: Illinois Edition 2005.

[40] Greenberg MT, Domitrovich CE, Bumbarger B. The prevention of mental disorders in school-aged children: Current state of the field. Prev Treat 2001; 4: 1-59.

[41] Greenberg MT. Current and future challenges in school-based prevention: the researcher perspective. Prev Sci 2004; 5(1): 5-13.

[42] Eisen M, Zellman GL, Murray DM. Evaluating the lions-quest "skills for adolescence" drug education program. Second-year behavior outcomes. Addict Behav 2003; 28(5): 883-97.

[43] Johnson KW, Shamblen SR, Ogilvie KA, et al. Preventing youths' use of inhalants and other harmful legal products in frontier Alaskan communities: A randomized trial. Prev Sci 2009; 10(4): 298312 .

[44] Spoth RL, Clair S, Shin C, Redmond C. Long-term effects of universal preventive interventions on methamphetamine use among adolescents. Arch Pediatr Adolesc Med 2006; 160(9): 876-82.

[45] Werch CE, Bian H, Moore MJ, et al. Brief multiple behavior health interventions for older adolescents. Am J Health Promot 2008; 23(2): 92-6.

[46] Bühler A, Schröder E, Silbereisen RK. The role of life skills promotion in substance abuse prevention: A mediation analysis. Health Educ Res 2008; 23(4): 621-32.

[47] Holen S, Waaktaar T, Lervag A, Ystgaard M. The effectiveness of a universal school based programme on coping and mental health: A randomized, controlled study of Zippys' Friend. Educ Psychol 2012; 32(5): 657-77.

[48] Huang CM, Chien LY, Cheng CF, Guo JL. Integrating life skills into a theory-based drug-use prevention program: Effectiveness among junior high students in Taiwan. J Sch Health 2012; 82(7): 328-35.
[49] Resnicow K, Reddy SP, James S, et al. Comparison of two schoolbased smoking prevention programs among South African high school students: Results of a randomized trial. Ann Behav Med 2008; 36(3): 231-43.

[50] Seal N. Preventing tobacco and drug use among Thai high school students through life skills training. Nurs Health Sci 2006; 8(3): 164-8.

[51] Walker D, Gutierrez JP, Torres P, Bertozzi SM. HIV prevention in Mexican schools: Prospective randomised evaluation of intervention. BMJ 2006; 332(7551): 1189-94.

[52] Bond L, Patton G, Glover S, et al. The gatehouse project: Can a multilevel school intervention affect emotional wellbeing and health risk behaviours? J Epidemiol Community Health 2004; 58(12): 997-1003.

[53] He M, Beynon C, Sangster Bouck M, et al. Impact evaluation of the Northern Fruit and Vegetable Pilot Programme - a clusterrandomised controlled trial. Public Health Nutr 2009; 12(11): 2199-208.

[54] Shek DT, Ma CM. Impact of the Project P.A.T.H.S. in the junior secondary school years: objective outcome evaluation based on eight waves of longitudinal data. Sci World J 2012; 2012: 170345.

[55] Jones SM, Brown JL, Lawrence AJ. Two-year impacts of a universal school-based social-emotional and literacy intervention: An experiment in translational developmental research. Child Dev 2011; 82(2): 533-54.

[56] Spoth RL, Randall GK, Trudeau L, et al. Substance use outcomes $51 / 2$ years past baseline for partnership-based, family-school preventive interventions. Drug Alcohol Depend 2008; 96(1-2): 57-68.

[57] Khalsa SB, Hickey-Schultz L, Cohen D, et al. Evaluation of the mental health benefits of yoga in a secondary school: A preliminary randomized controlled trial. J Behav Health Serv Res 2012; 39(1): 80-90.

[58] Young DR, Phillips JA, Yu T, Haythornthwaite JA. Effects of a life skills intervention for increasing physical activity in adolescent girls. Arch Pediatr Adolesc Med 2006; 160(12): 1255-61.

[59] Melnyk BM, Jacobson D, Kelly S, et al. Promoting healthy lifestyles in high school adolescents: A randomized controlled trial. Am J Prev Med 2013; 45(4): 407-15.

[60] Noggle JJ, Steiner NJ, Minami T, Khalsa SB. Benefits of yoga for psychosocial well-being in a US high school curriculum: A preliminary randomized controlled trial. J Dev Behav Pediatr 2012; 33(3): 193-201.

[61] Stage SA, Quiroz DR. A meta-analysis of interventions to decrease disruptive classroom behaviour in public education settings. Sch Psychol Rev 1997; 26: 333-68.

[62] Dirks MA, Treat TA, Weersing VR. Integrating theoretical, measurement, and intervention models of youth social competence. Clin Psychol Rev 2007; 27: 327-47.

[63] Wagnild GM, Young HM. Development and psychometric evaluation of the resilience scale. J Nurs Meas 1993; 1: 165-78.

[64] Spirito A, Stark LJ, Williams C. Development of a brief coping checklist for use with pediatric populations. J Pediatr Psychol 1988; 13(4): 555-74.

[65] Pechman EM, Russell CA, Birmingham J. Out-of-school time (OST) observation instrument: Re-port of the validation study. Washington, DC: Policy Studies Associates, Inc 2008.

[66] Osher D, Dwyer K, Jackson S. Safe, supportive and successful schools, step by step. Rockville, MD: US Department of Health and Human Services, Substance Abuse and Mental Health Services Administration, Center for Mental Health Services 2002.

[67] Weissberg RP, Greenberg MT. School and community competence-enhancement and prevention programs. In: Siegel IE, Renninger KA, Eds. Handbook of child psychology. Child psychology in practice. $5^{\text {th }}$ ed. New York: Wiley 1998; 4: pp. 877954.

[68] Eisen M, Zellman GL, Massett HA, Murray DM. Evaluating the lions-quest "skills for adolescence" drug education program: firstyear behavior outcomes. Addict Behav 2002; 27(4): 619-32.

[69] Spoth RL, Redmond C, Trudeau L, Shin C. Longitudinal substance initiation outcomes for a universal preventive intervention combining family and school programs. Psychol Addict Behav 2002; 16(2): 129-34.

[70] Spoth R, Randall GK, Redmond C, Shin C. Randomized study of combined universal family and school preventive interventions: Patterns of long-term effects on initiation, regular use and weekly drunkenness. Psychol Addict Behav 2005; 19: 372-81. 
[71] Shek DT, Siu AMH, Lee TY, et al. Effectiveness of the tier 1 program of project P.A.T.H.S.: Objective outcome evaluation based on a randomized group trial. Sci World J 2008; 8: 4-12.

[72] Shek DT, Sun RCF. Effectiveness of the tier 1 program of project P.A.T.H.S.: Findings based on three years of program implementation. Sci World J 2010; 10: 1509-19.

[73] Shek DT . Objective outcome evaluation of the project P.A.T.H.S. in Hong Kong: findings based on individual growth curve models. Sci World J 2010; 10: 182-91.
[74] Shek DT, Ma CM. Impact of the project P.A.T.H.S. in the junior secondary school years: Individual growth curve analyses. Sci World J 2011; 10: 253-66.

[75] Shek DT, Yu L. Prevention of adolescent problem behavior: Longitudinal impact of the project P.A.T.H.S. in Hong Kong. Sci World J 2011; 11: 546-67.

[76] Shek DT, Ma CM. Impact of project P.A.T.H.S. on adolescent developmental outcomes in Hong Kong: Findings based on seven waves of data. Int J Adolesc Med Health 2012; 24(3): 231-44.

Received: September 16, 2014

Revised: September 19, 2014

Accepted: October 06, 2014

(C) Sancassiani et al.; Licensee Bentham Open.

This is an open access article licensed under the terms of the Creative Commons Attribution Non-Commercial License (http://creativecommons.org/licenses/by-nc/3.0/) which permits unrestricted, non-commercial use, distribution and reproduction in any medium, provided the work is properly cited. 